\title{
Novel highly active carbon supported ternary PdNiBi nanoparticles as anode catalyst for the alkaline direct ethanol fuel cell
}

\author{
Bernd Cermenek $^{1}(\bowtie)$, Johanna Ranninger ${ }^{1}$, Birgit Feketeföldi ${ }^{2}$, Ilse Letofsky-Papst ${ }^{3}$, Norbert Kienzl ${ }^{4}$, Brigitte Bitschnau ${ }^{5}$, \\ and Viktor Hacker ${ }^{1}(\bowtie)$ \\ ${ }^{1}$ Institute of Chemical Engineering and Environmental Technology, Graz University of Technology, NAWI Graz, Inffeldgasse 25/C, 8010 Graz, Austria \\ ${ }^{2}$ Institute for Surface Technologies and Photonics, JOANNEUM RESEARCH Forschungsgesellschaft mbH/Materials, Franz-Pichler-Straße 30 , 8160 \\ Weiz, Austria \\ ${ }^{3}$ Institute for Electron Microscopy and Nanoanalysis and Center for Electron Microscopy, Graz University of Technology, NAWI Graz, Steyrergasse \\ 17, 8010 Graz, Austria \\ ${ }^{4}$ Bioenergy 2020+ GmbH, Inffeldgasse 21/B, 8010 Graz, Austria \\ ${ }^{5}$ Institute of Physical and Theoretical Chemistry, Graz University of Technology, Streymayrgasse 9, 8010 Graz, Austria
}

(C) The Author(s) 2019

Received: 14 October 2018 / Revised: 16 December 2018 / Accepted: 21 December 2018

\begin{abstract}
The study focuses on the influence of $\mathrm{Ni}$ and $\mathrm{Bi}$ on alkaline ethanol oxidation reaction (EOR) activities, stabilities and structure characteristics of carbon supported $\mathrm{Pd}$-based nanocatalysts $\left(\mathrm{Pd} / \mathrm{C}, \mathrm{Pd}_{60} \mathrm{Ni}_{40} / \mathrm{C}, \mathrm{Pd}_{60} \mathrm{Bi}_{40} / \mathrm{C}, \mathrm{Pd}_{60} \mathrm{Ni}_{20} \mathrm{Bi}_{20} / \mathrm{C}\right)$ by cyclic voltammetry/chronoamperometry using rotating disk electrode and various physico-chemical methods such as X-ray powder diffraction, X-ray photoelectron spectroscopy, transmission electron microscopy coupled with energy dispersive X-ray spectroscopy and inductively coupled plasma optical emission spectrometry. Nickel generates more adsorbed $\mathrm{OH}$ on the $\mathrm{Pd}$ catalyst surface than $\mathrm{Bi}$ and promotes the oxidation of adsorbed ethanol species. This results in a low onset potential toward ethanol oxidation with high current density. The presence of Bi facilitates high tolerance toward various reaction intermediates resulting from the incomplete ethanol oxidation, but might also initiate the agglomeration of $\mathrm{Pd}$ nanoparticles. The novel $\mathrm{Pd}_{60} \mathrm{Ni}_{20} \mathrm{Bi}_{20} / \mathrm{C}$ nanocatalyst displays exceptional byproduct tolerance, but only satisfying catalytic activity toward ethanol oxidation in an alkaline medium. Therefore, the EOR performance of the novel carbon supported ternary $\mathrm{Pd}_{x} \mathrm{Ni}_{y} \mathrm{Bi}_{z}$ anode catalyst with various atomic variations $\left(\mathrm{Pd}_{70} \mathrm{Ni}_{25} \mathrm{Bi}_{5} / \mathrm{C}, \mathrm{Pd}_{70} \mathrm{Ni}_{20} \mathrm{Bi}_{10} / \mathrm{C}, \mathrm{Pd}_{80} \mathrm{Ni}_{10} \mathrm{Bi}_{10} / \mathrm{C}\right.$ and $\left.\mathrm{Pd}_{40} \mathrm{Ni}_{20} \mathrm{Bi}_{40} / \mathrm{C}\right)$ using the common instant reduction synthesis method was further optimized for the alkaline direct ethanol fuel cell. The carbon supported Pd:Ni:Bi nanocatalyst with atomic ratio of 70:20:10 displays outstanding catalytic activity for the alkaline EOR compared to the other $\mathrm{Pd}_{x} \mathrm{Ni}_{y} \mathrm{Bi}_{z} / \mathrm{C}$ nanocatalysts as well as to the benchmarks $\mathrm{Pd} / \mathrm{C}, \mathrm{Pd}_{60} \mathrm{Ni}_{40} / \mathrm{C}$ and $\mathrm{Pd} \mathrm{d}_{60} \mathrm{Bi}_{40} / \mathrm{C}$. The synergy and the optimal content in consideration of the oxide species of $\mathrm{Pd}, \mathrm{Ni}$ and $\mathrm{Bi}$ are crucial for the EOR kinetic enhancement in alkaline medium.
\end{abstract}

\section{KEYWORDS}

alkaline direct ethanol fuel cell, catalytic activity, ethanol oxidation reaction, ternary PdNiBi nanocatalysts, structure characteristics

\section{Introduction}

The alkaline direct ethanol fuel cell (ADEFC) using non-Pt-based electrocatalysts, and cost-efficient materials to produce anion exchange membranes (AEMs), is a low-cost, environment-friendly and easyhandling energy source as an alternative to batteries for small-scale portable applications [1].

The ADEFC exhibits the following benefits compared to other low temperature fuel cells:

1) Ethanol is a sustainable, low-toxic, liquid fuel with high volumetric energy density $\left(6.3 \mathrm{kWh} \cdot \mathrm{L}^{-1}\right)$ compared to methanol $\left(4.8 \mathrm{kWh} \cdot \mathrm{L}^{-1}\right)$ and hydrogen $\left(2.6 \mathrm{kWh} \cdot \mathrm{L}^{-1}\right)$ and thereby easy to handle, store and transport [1-6].

2) The production of ethanol from agricultural products or biomass e.g. straw, corn, sugar cane or wheat compared to methanol and hydrogen avoids the use of limited availability fossil fuels as feedstocks $[3,5]$.

3) The usage of alkaline electrolytes leads to the following improvements: a) The kinetics of ethanol oxidation reaction (EOR) and oxygen reduction reaction (ORR) are enhanced [1-6]. b) Non-noble elements (e.g. $\mathrm{Ni}, \mathrm{Fe}, \mathrm{Co}, \mathrm{Bi}$ or $\mathrm{Mn}$ ) as admetals are used for the production of EOR and ORR catalysts to reduce the catalytic material costs and to enhance their catalytic performance [1-9]. c) The use of the AEM instead of the cation exchange membrane (CEM) lowers the costs (AEM: $67.5 \$ \cdot \mathrm{m}^{-2}$ vs. CEM: $675 \$ \cdot \mathrm{m}^{-2}$ ) [1]. d) Due to the reversed direction of ion conduction of AEMs (electro osmotic drag) compared to CEMs, the ethanol-crossover is drastically reduced in the ADEFC $[6,10]$.

The main challenge of ADEFC, however, is to develop a highly efficient anode catalyst for complete oxidation of ethanol to use the total chemical energy stored in ethanol molecule in electricity. Currently, there is no catalyst which cleaves the carbon-carbon bond of ethanol resulting in a $\mathrm{CO}_{2}$ efficiency of $100 \%$ according to $\mathrm{C} 1$ pathway (Scheme 1) at low temperatures due to mechanistic and/or sterical effects [11].

The reaction mechanism of the ethanol oxidation on the currently used catalysts predominantly takes place on the $\mathrm{C} 2$ pathway (Scheme 2), resulting in various reaction intermediate deposits on 
$\mathrm{CH}_{3} \mathrm{CH}_{2} \mathrm{OH} \rightarrow \mathrm{CH}_{3} \mathrm{CHO}_{\text {ads }} \rightarrow \mathrm{CO}_{\text {ads }}, \mathrm{CH}_{x, \text { ads }} \rightarrow \mathrm{CO}_{2}$ or $\mathrm{CO}_{3}{ }^{2-}$

Scheme 1 Alkaline ethanol electrooxidation according to $\mathrm{C} 1$ pathway.

\section{$\mathrm{CH}_{3} \mathrm{CH}_{2} \mathrm{OH} \rightarrow \mathrm{CH}_{3} \mathrm{CHO}_{\text {ads }} \rightarrow \mathrm{CH}_{3} \mathrm{CHO} / \mathrm{CH}_{3} \mathrm{COOH}$ or $\mathrm{CH}_{3} \mathrm{COO}^{-}$}

Scheme 2 Alkaline ethanol electrooxidation according to C2 pathway.

the active sites of the catalyst with a decrease of its performance. The main products of alkaline EOR, generated by the reaction between adsorbed ethanol and adsorbed $\mathrm{OH}$ on the present catalysts, are acetic acid $\left(\mathrm{CH}_{3} \mathrm{COOH}\right)$ and/or acetate $\left(\mathrm{CH}_{3} \mathrm{COO}^{-}\right)$[11].

The resulting reaction intermediates during the alkaline EOR deactivate easily the carbon supported Pt-based catalysts and reduce their efficiencies over time for the use in ADEFC [12-14]. Therefore, binary and ternary Pt-free catalysts are preferentially used for the alkaline EOR.

Carbon supported $\mathrm{Pd}(\mathrm{Pd} / \mathrm{C})$ as monometallic catalyst exhibits the best performance for the alkaline EOR compared to the other noble metals e.g. Pt and $\mathrm{Au}[14,15]$ and is also more cost efficient than the others [1]. The addition of oxophilic elements such as $\mathrm{Ni}, \mathrm{Bi}$, $\mathrm{Ru}, \mathrm{Sn}, \mathrm{Zn}$ or P improves the catalytic stability including tolerance to poisonous species such as $\mathrm{CO}$ resulting from the ethanol oxidation process ( $\rightarrow$ byproduct-tolerance) and activity (onset potential and peak current density or mass activity) of Pd catalysts with bi- and polymetallic compositions due to bifunctional, electronic and synergetic effects $[2,4,7,12,16-20]$. The poisoning of catalysts by reaction intermediates of the incomplete ethanol oxidation thus depends in particular on the nature of the catalyst used.

The carbon supported bismuth (Bi/C) and nickel (Ni/C) electrocatalysts display no activities to alkaline EOR in the potential useful range $[2,7,21,22]$. A certain amount of $\mathrm{Bi}$ and $\mathrm{Ni}$ as elemental additives (oxophilic elements) however, improve the alkaline EOR performance of Pd-based catalysts considerably [7, 22, 23].

Nickel is often used as co-catalyst in Pd-based anode catalysts and promotes their alkaline EOR activities and stabilities for the ADEFC. One of many studies here, for example that of Shen and co-workers confirms the performance improvement achieved by developing and testing of $\mathrm{Pd}_{x} \mathrm{Ni}_{y} / \mathrm{C}(\mathrm{C}=$ Vulcan XC72R) catalysts with various atomic ratios. The enhancement of the alkaline EOR catalytic activities was explained due to the affinity of $\mathrm{Ni}$ to form $\mathrm{Ni}-\mathrm{OH}_{\text {ads }}$ species which facilitate the oxidation process to $\mathrm{CH}_{3} \mathrm{COOH}$ through a bifunctional mechanism and also by oxidative removal of poisonous ethanol species from the catalyst surface. Furthermore, the alkaline EOR performances of Pd-based electrocatalyst depend on the Ni content which leads to a decrease in alkaline EOR activity when it is too high due to the presence of $\mathrm{Ni}$ oxide species with low conductivity [4].

Shen et al. developed a carbon supported Pd-NiO catalyst with lower onset potential and higher current density toward the alkaline EOR compared to other $\mathrm{Pd}$-oxide/C catalyst. The $\mathrm{Pd}-\mathrm{NiO} / \mathrm{C}$ anode catalyst shows higher byproduct tolerance of ethanol oxidation than Pt-based catalysts [16].

Neto et al. show the influence of $\mathrm{Bi}$ on the alkaline EOR performances of carbon supported binary $\mathrm{Pd}_{x} \mathrm{Bi}_{y}$ catalysts $\left(\mathrm{Pd}_{x} \mathrm{Bi}_{y} / \mathrm{C}\right.$, $\mathrm{C}=$ Vulcan XC72R) with various atomic ratios of (95:05), (90:10), (80:20) and (70:30) using cyclic voltammetry for determination of their catalytic activities in comparison to a carbon supported monometallic Pd/C catalyst. The Bi content of 5 at.\% and 10 at.\% in $\mathrm{Pd}$ catalysts shifts the onset potentials toward the alkaline EOR to lower potentials in contrast with $\mathrm{Pd} / \mathrm{C}$. The $\mathrm{PdBi} / \mathrm{C}$ with the atomic ratio of (95:5) exhibits the best results relating to electrocatalytic activity and stability compared to the other catalysts. This study reveals that the kinetics of alkaline EOR and the byproduct tolerance on PdBi catalysts with low $\mathrm{Bi}$ content are improved by the oxidative removal of adsorbed ethoxy species (rate-determining step; Scheme 2) from the catalytic sites of $\mathrm{Pd}[7]$.
The third element in carbon supported ternary anode catalysts for the ADEFC can additionally improve or strengthen the alkaline EOR performances of the catalyst relating to catalytic activity (onset potential and current density), long-term stability and byproduct tolerance compared to carbon supported binary EOR catalysts $[9,19,24-35]$.

For example, the addition of $\mathrm{P}$ and $\mathrm{Zn}$ to carbon supported $\mathrm{PdNi}$ catalyst $(\mathrm{PdNi} / \mathrm{C}, \mathrm{C}=$ Vulcan XC72R), forming ternary PdNiP/C and $\mathrm{PdNiZn} / \mathrm{C}$ catalysts which exhibit higher EOR activity (lower onset potential and higher peak current) than the binary $\mathrm{PdNi} / \mathrm{C}$ catalyst $[2,9,36]$.

Zhu et al. investigated the influence of elemental additives as $\mathrm{Ni}$, Co and Ag on the electrocatalytic activities of binary PdSn-based catalysts for alkaline EOR. This study demonstrated that the PdSnbased catalyst alloyed with Ag exhibited the best results related to intrinsic activity and stability toward alkaline ethanol oxidation [19].

In this study, the influence of $\mathrm{Ni}$ and $\mathrm{Bi}$ on the alkaline EOR performance and the structure of carbon supported $\mathrm{Pd}$-based nanocatalysts $\left(\mathrm{Pd} / \mathrm{C}, \mathrm{Pd}_{60} \mathrm{Ni}_{40} / \mathrm{C}, \mathrm{Pd}_{60} \mathrm{Bi}_{40} \mathrm{C}, \mathrm{Pd}_{x} \mathrm{Ni}_{y} \mathrm{Bi}_{z} / \mathrm{C}\right)$ were investigated by electrochemical and various physico-chemical methods. The optimization of the atomic composition of the novel carbon supported ternary $\mathrm{Pd}_{x} \mathrm{Ni}_{y} \mathrm{Bi}_{z}$ catalyst was performed to improve its catalytic activity and stability for the alkaline EOR using the common instant reduction synthesis method with $\mathrm{NaBH}_{4}$ as reducing agent for the ADEFC.

\section{Experimental}

\subsection{Chemicals and materials}

Palladium chloride ( $\mathrm{PdCl}_{2}$, anhydrous, $59 \%-60 \% \mathrm{Pd}$ basis, Aldrich), sodium chloride ( $\mathrm{NaCl} ; \geq 99.5 \%$, Aldrich), nickel nitrate hexahydrate $\left(\mathrm{Ni}\left(\mathrm{NO}_{3}\right)_{2} \cdot 6 \mathrm{H}_{2} \mathrm{O}\right.$, Aldrich), bismuth(III) chloride $\left(\mathrm{BiCl}_{3}\right.$, reagent grade, $\geq 98 \%$, Aldrich), hydrochloric acid ( $\mathrm{HCl}$ p.a. $\geq 32 \%$, Fluka Analytics), Vulcan XC72R carbon black (CABOT Corporation, USA), sodium borohydride $\left(\mathrm{NaBH}_{4}\right.$, Sigma-Aldrich), 2-propanol (ASC $\geq$ 99.8\%, Sigma-Aldrich), sodium hydroxide ( $\mathrm{NaOH}$, Aldrich), $1.0 \mathrm{M}$ potassium hydroxide standard solution (KOH, FIXANAL KA $180 \mathrm{~mL}$, Sigma-Aldrich), Nafion ionomer solution (5 wt.\%, Quintech), ethanol abs. (99.999\%, Aldrich), and ultra-pure water $(\approx 18 \mathrm{M} \Omega \cdot \mathrm{cm}$, Barnstead NANOpure Water Purification system) were used for all in this study performed experiments.

\subsection{Synthesis of ternary $\mathrm{Pd}_{x} \mathrm{Ni}_{y} \mathrm{Bi}_{z} / \mathrm{C}$ nanocatalysts}

The carbon supported $\mathrm{Pd}_{x} \mathrm{Ni}_{y} \mathrm{Bi}_{z}$ nanocatalysts were synthesized by means of the instant reduction method using $\mathrm{NaBH}_{4}$ as a reducing agent [37-40]. Firstly, $\mathrm{PdCl}_{2}$ and $\mathrm{NaCl}$ were completely dissolved in $10 \mathrm{~mL}$ of ultra-pure water using an ultrasonic bath for several hours. The added $\mathrm{NaCl}$ causes a better solubility of $\mathrm{PdCl}_{2}$ in ultra-pure water due to complex formation of sodium tetrachloropalladate $\left(\mathrm{Na}_{2}\left[\mathrm{PdCl}_{4}\right]\right)$ (Eq. (1)).

$$
\mathrm{PdCl}_{2}+2 \mathrm{NaCl} \rightarrow \mathrm{Na}_{2}\left[\mathrm{PdCl}_{4}\right]
$$

$\mathrm{Ni}\left(\mathrm{NO}_{3}\right)_{2} \cdot 6 \mathrm{H}_{2} \mathrm{O}$ and $\mathrm{BiCl}_{3}$ were dissolved in $10 \mathrm{~mL}$ of ultra-pure water. $\mathrm{A}$ few drops of $\mathrm{HCl}$ were added to the $\mathrm{BiCl}_{3}$ solution to dissolve the precipitated bismuth oxychloride $(\mathrm{BiOCl})$. These dissolved precursor salts were added to the $\mathrm{Na}_{2}\left[\mathrm{PdCl}_{4}\right]$ solution in a definite stoichiometry. Vulcan XC72R carbon black as support material was suspended in $54 \mathrm{~mL}$ of 2-propanol and $6 \mathrm{~mL}$ of ultra-pure water for $0.5 \mathrm{~h}$ using an ultrasonic bath. The metal salt solutions were added with additional $40 \mathrm{~mL}$ of ultra-pure water to suspended carbon support material (catalyst composition: $40 \mathrm{wt} . \%$ of metals and 60 wt.\% of carbon support material). The $\mathrm{pH}$ of the metal salts containing solution was adjusted to 10 using $5 \mathrm{M} \mathrm{NaOH}$. After drop-wise addition of the reducing agent solution $\left(\sim 3\right.$ eq. of $\mathrm{NaBH}_{4}(\mathrm{~s})$ 
in $0.6 \mathrm{~mL}$ of $1 \mathrm{M} \mathrm{NaOH}$ and $6 \mathrm{~mL}$ of ultra-pure water) to the salt suspension, the reaction mixture was vigorously stirred at $60{ }^{\circ} \mathrm{C}$ for $4 \mathrm{~h}$ to reduce to respective metals on carbon support material Vulcan $\mathrm{XC72R}$, giving the corresponding $\mathrm{Pd}_{x} \mathrm{Ni}_{y} \mathrm{Bi}_{z} / \mathrm{C}$. After cooling of the reaction mixture to room temperature $(\mathrm{rt})$, multiple washing (three times) of the catalyst suspension was performed with ultra-pure water including centrifugation at 3,500 $\mathrm{rpm}$ for $30 \mathrm{~min}$. After each washing process, the water was decanted from the product. Finally, the obtained cleaned carbon supported $\mathrm{Pd}_{x} \mathrm{Ni}_{y} \mathrm{Bi}_{z}$ nanoparticles were dried at $80^{\circ} \mathrm{C}$ until constant weight was adjusted.

The syntheses of the other Pd-based nanocatalysts ( $\mathrm{Pd} / \mathrm{C}, \mathrm{Pd}_{60} \mathrm{Ni}_{40} / \mathrm{C}$ and $\mathrm{Pd}_{60} \mathrm{Bi}_{40} / \mathrm{C}$ ) were performed by the same procedure as for the development of $\mathrm{Pd}_{x} \mathrm{Ni}_{y} \mathrm{Bi}_{z} / \mathrm{C}$ nanocatalysts.

\subsection{Physico-chemical characterization}

The actual elemental composition of each catalyst was analyzed by inductively coupled plasma optical emission spectrometry (ICP-OES). Metal concentrations of catalysts were determined by this method after microwave-assisted pressurized acid digestion. A Multiwave 3000 microwave system (Anton Paar, Graz, Austria) was used for digestion. Each material was analyzed in triplicate by digesting 5-10 mg of catalyst with $7 \mathrm{~mL}$ of concentrated nitric acid and $0.2 \mathrm{~mL}$ of $\mathrm{HClO}_{4}$ (Carl Roth, Karlsruhe, Germany). Temperature was ramped to $195^{\circ} \mathrm{C}$ within 15 min with the application of $1,500 \mathrm{~W}$ of power, followed by a dwell time of $25 \mathrm{~min}$ at maximum temperature. Samples were diluted to $25 \mathrm{~mL}$ with deionized water. The ICP-OES system was an Arcos SOP by Spectro (Kleve, Germany). Following detection wavelengths were used for each element: $\mathrm{Bi}$ $223.061 \mathrm{~nm}$, Ni $231.604 \mathrm{~nm}$, Pd $340.458 \mathrm{~nm}$. Sample blanks and spikes were included in all preparation procedures.

The morphology, particle size distribution and the chemical composition (atomic ratio) of each catalyst were determined by means of the transmission electron microscopy coupled with energy dispersive X-ray spectroscopy (TEM-EDX), respectively. The images were acquired using a monochromated TF20 TEM (FEI) equipped with a Schottky field emission gun and operated at $200 \mathrm{kV}$. The EDX spectra were detected with an EDAX $\mathrm{Si}(\mathrm{Li})$ detector. For preparing the TEM grids, we followed the standard preparation procedure for powder samples by depositing a drop of alcohol suspended sample particles onto a copper TEM grid which was covered with a holey carbon support-film.

The structural composition from each synthesized catalyst was investigated with X-ray powder diffraction (XRD), using a Bruker D8-Advance diffractometer with Lynxeye detector. XRD measurements were performed from $20^{\circ}$ to $100^{\circ} 2 \theta$, with a step size of $0.02^{\circ}$ and a scan time of $2 \mathrm{~s}$ per step. $\mathrm{Cu}-\mathrm{K} \alpha$ radiation $(\lambda=0.15418 \mathrm{~nm})$ was used for the XRD analysis. Lattice parameters and peak-widths were calculated with Rietveld method, using PANalytical X'Pert Highscore Plus software. An estimation of mean crystallite size was performed using Scherrer-method.

The X-ray photoelectron spectroscopy (XPS) is a qualitative and quantitative method to find more information about the chemical composition from the binding energies of core-level-electrons of each contained element in synthesized catalysts. The X-ray photoelectron spectrometer works under ultrahigh-vacuum (UHV) conditions with a residual gas pressure below $10^{-10}$ mbar. Each catalyst sample was transferred into the analysis-chamber within several hours via load-lock. The system is also equipped with a UV-photoelectron spectrometer. The following instrumentation is used for XPS-analysis: "Multiprobe" UHV-surface-analysis system (Omicron Nanotechnology); X-ray source: DAR400 aluminium-anode; quartz-crystal monochromator XM 500; X-ray excitation energy: $1,486.70 \mathrm{eV}$ (Al K $\alpha 1$-line); monochromated X-ray line width (FWHM): $0.3 \mathrm{eV}$; energy analyzer: hemispherical analyzer, type EA 125 signal-detection with pulse-counting channeltron.

\subsection{Electrochemical characterization}

The EOR activities and stabilities of carbon supported Pd-based electrocatalysts were determined by means of cyclic voltammetry (CV) and chronoamperometry (CA) using a rotating disk electrode (RDE; Model AFE5T050GC from PINE Research Instrumentation), respectively [37, 40-42].

The electrochemical measurements were performed in an electrochemical glass cell (Metrohm) with a three-electrode-arrangement consisting of platinized titanium rod (Bank Elektronik - Intelligent controls $\mathrm{GmbH}$ ) as counter electrode, reversible hydrogen electrode (RHE; HydroFlex ${ }^{\circledR}$, gaskatel) as reference electrode and RDE as working electrode. A GAMRY (bi-)potentiostat (Reference 600TM Potentiostat/Galvanostat/ZRA, GAMRY Instruments Inc., Pennsylvania, USA) was used as control system. Before starting the electrochemical measurement, the RDE with glassy carbon substrate (geometric area: $0.196 \mathrm{~cm}^{2}$ ) was polished using $0.05 \mu \mathrm{m}$ alumina suspension (MasterPrep ${ }^{\circledR}$ Polishing Suspension; Buehler) and was finally rinsed with ultra-pure water.

The synthesized catalysts were dissolved in a mixture of $1.75 \mathrm{~mL}$ of 2-propanol, $0.737 \mathrm{~mL}$ of ultra-pure water and $13 \mu \mathrm{L}$ of Nafion ionomer solution (5 wt.\%, Quintech) as binder and were sonicated for $15 \mathrm{~min}$ in an ice-bath until a homogeneous dispersion was formed. An appropriate amount of catalyst ink was dropped onto the RDE in order to achieve the desired loading of $56 \mu \mathrm{g}_{\mathrm{Pd}} \cdot \mathrm{cm}^{-2}$. The RDE with the catalyst ink was dried by rotation to air at a rotation speed of $700 \mathrm{rpm}$ for approximately $1.5 \mathrm{~h}$. In the meantime, the alkaline electrolyte (1.0 M potassium hydroxide standard solution; FIXANAL KA $180 \mathrm{~mL}$, Sigma-Aldrich) was purged with nitrogen gas $\left(\mathrm{N}_{2}\right.$, purity of 5.0, Air Liquide) for $30 \mathrm{~min}$ to remove the dissolved oxygen out of it, before the measurements were started. After that, the RDE with the respective catalyst was immersed in the $1.0 \mathrm{M} \mathrm{KOH}$, saturated with nitrogen and CVs of each catalyst were recorded at a scan rate of $50 \mathrm{mV} \cdot \mathrm{s}^{-1}$ (cleaning cycles are fast oxidation and reduction processes to remove the impurities from the surface of the catalyst) and finally at a scan rate of $10 \mathrm{mV} \cdot \mathrm{s}^{-1}$ in a stationary condition, respectively. After the addition of $1.0 \mathrm{M}$ ethanol (purchased from ethanol absolute, $99.999 \%$, Aldrich) to $1.0 \mathrm{M} \mathrm{KOH}$, further CVs of each catalyst was also recorded at a scan-rate of $10 \mathrm{mV} \cdot \mathrm{s}^{-1}$ to determine the specific activity toward the ethanol oxidation in an alkaline medium.

Finally, all synthesized Pd-based catalysts were applied at a constant potential of $0.83 \mathrm{~V}$ for $1 \mathrm{~h}$ under the same operating conditions as for CV-measurements to investigate their catalytic stabilities.

\section{Results and discussion}

\subsection{Physico-chemical characterization}

An extensive physico-chemical characterization is very important for a better interpretation and understanding of performances of all synthesized nanocatalysts for the alkaline EOR. Pd-based nanocatalysts were analyzed by various methods, such as, ICP-OES, TEM-EDX, XRD and XPS in this study.

ICP-OES is an appropriate method for the quantitative determination of the elemental concentrations of the carbon supported Pd, $\mathrm{Pd}_{x} \mathrm{Ni}_{y}, \mathrm{Pd}_{x} \mathrm{Bi}_{y}$ and various $\mathrm{Pd}_{x} \mathrm{Ni}_{y} \mathrm{Bi}_{z}$ catalysts with the calculated atomic ratio of (100), (60:40), (60:40), and (60:20:20), (70:25:5), (70:20:10), (80:10:10), (40:20:40). Analysis results by ICP-OES are in good agreement with calculated values (= subscripts of catalysts) from the preparation of nanocatalysts (Table 1, detailed in Table S1 in the Electronic Supplementary Material (ESM)).

Metal nanoparticles (black) of the $\mathrm{Pd} / \mathrm{C}$ catalyst are more evenly distributed on the carbon support material Vulcan XC72R (grey) than the bi- and ternary Pd-based catalysts. It can be observed that the presence of $\mathrm{Bi}$ and $\mathrm{Ni}$ in carbon supported Pd-based catalysts 
apparently causes an agglomeration of the metal nanoparticles (Figs. 1(a)-1(d), and Figs. S1 and S2(a)-S2(d) in the ESM). It is very difficult to determine the particle size of these catalysts, because insufficient spherical particles are presented for showing reproducible results due to the agglomeration.

Table 1 Elemental analysis of Pd-based nanocatalysts by ICP-OES

\begin{tabular}{cccc}
\hline Catalysts & $\mathrm{Pd}($ at.\%) & $\mathrm{Ni} \mathrm{(at. \% )}$ & $\mathrm{Bi} \mathrm{(at. \% )}$ \\
\hline $\mathrm{Pd} / \mathrm{C}$ & 100 & - & - \\
$\mathrm{Pd}_{60} \mathrm{Ni}_{40} / \mathrm{C}$ & 60 & 40 & - \\
$\mathrm{Pd}_{60} \mathrm{Bi}_{40} / \mathrm{C}$ & 61 & - & 39 \\
$\mathrm{Pd}_{60} \mathrm{Ni}_{20} \mathrm{Bi}_{20} / \mathrm{C}$ & 61 & 19 & 20 \\
$\mathrm{Pd}_{70} \mathrm{Ni}_{25} \mathrm{Bi}_{5} / \mathrm{C}$ & 71 & 24 & 5 \\
$\mathrm{Pd}_{70} \mathrm{Ni}_{20} \mathrm{Bi}_{10} / \mathrm{C}$ & 70 & 19 & 11 \\
$\mathrm{Pd}_{80} \mathrm{Ni}_{10} \mathrm{Bi}_{10} / \mathrm{C}$ & 78 & 10 & 12 \\
$\mathrm{Pd}_{40} \mathrm{Ni}_{20} \mathrm{Bi}_{40} / \mathrm{C}$ & 46 & 17 & 37 \\
\hline
\end{tabular}
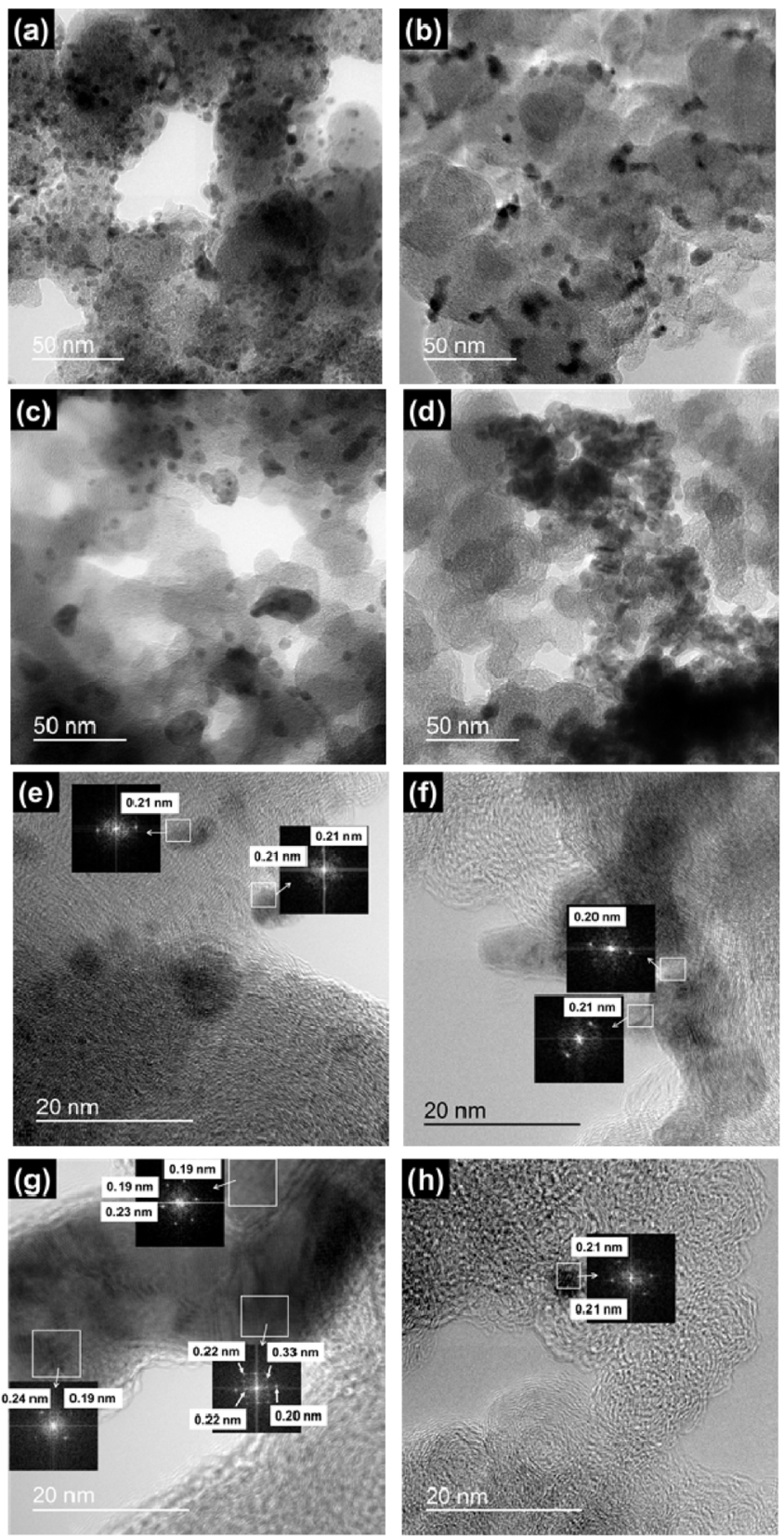

Figure 1 TEM micrographs of the (a) $\mathrm{Pd} / \mathrm{C}$, (b) $\mathrm{Pd}_{60} \mathrm{Ni}_{40} / \mathrm{C}$, (c) $\mathrm{Pd}_{60} \mathrm{Bi}_{40} / \mathrm{C}$ and (d) $\mathrm{Pd}_{60} \mathrm{Ni}_{20} \mathrm{Bi}_{20} / \mathrm{C}$ catalyst. HRTEM micrographs including the determined interplanar spacing of the (e) $\mathrm{Pd} / \mathrm{C}$, (f) $\mathrm{Pd}_{60} \mathrm{Ni}_{40} / \mathrm{C}$, (g) $\mathrm{Pd}_{60} \mathrm{Bi}_{40} / \mathrm{C}$ and (h) $\mathrm{Pd}_{60} \mathrm{Ni}_{20} \mathrm{Bi}_{20} / \mathrm{C}$ catalyst.
Applying fast Fourier transformation (FFT) on high resolution TEM (HRTEM) micrographs show that all carbon supported Pdbased catalysts exhibit inter-planar spacing of $\approx 0.21 \mathrm{~nm}$ determined which complies with lattice spacing of Pd (111) (Figs. 1(e)-1(h) and Figs. S2(e)-S2(h) in the ESM). Furthermore, scanning transmission electron microscopy high-angle angular dark-field imaging (STEMHAADF) was used to determine semi-quantitatively the metal contents of the carbon supported Pd-based catalysts at specific chosen areas by recording of EDX spectra (Figs. S3-S7 in the ESM). This analysis confirms that the metal nanoparticles of bi- and ternary Pd-based catalysts are not homogeneously distributed on the carbon support material (further details in the ESM).

The instant reduction method using $\mathrm{NaBH}_{4}$ as reducing agent is therefore not the optimal catalyst synthesis method especially for controlling the homogeneous deposition of bi- and tri-metallic nanoparticles on carbon support material. Alternatively, nanocapsule, aqueous solution phase synthesis or the polyol method are other synthesis procedures to minimize the agglomeration effect for polymetallic catalysts $[2,9,43]$.

The XRD patterns of all carbon supported Pd-based catalysts exhibit the typical diffraction peaks approx. at the $2 \theta$ values of $40^{\circ}$, $47^{\circ}, 68^{\circ}, 82^{\circ}$ and $86^{\circ}$ which can be assigned to the Pd face-centered cubic (fcc) crystalline structure (Pd_64922-ICSD) with miller indices of (111), (200), (220), (311) and (222), respectively (Fig. 2 and Fig. S8 in the ESM) $[2,4]$. The diffraction peak located approx. at the $2 \theta$ value of $25^{\circ}$ attributes to carbon black Vulcan XC72R as crystalline structure of graphite $(2 \mathrm{H})$ _187640-ICSD with the miller indices of (002) for all catalyst samples (Fig. 2 and Fig. S8 in the ESM) [2, 4].

The $2 \theta$ values of the binary and ternary catalysts $\left(\mathrm{Pd}_{60} \mathrm{Ni}_{40} / \mathrm{C}\right.$, $\mathrm{Pd}_{60} \mathrm{Bi}_{40} / \mathrm{C}, \mathrm{Pd}_{60} \mathrm{Ni}_{20} \mathrm{Bi}_{20} / \mathrm{C}, \mathrm{Pd}_{70} \mathrm{Ni}_{20} \mathrm{Bi}_{10} / \mathrm{C}$ and $\mathrm{Pd}_{40} \mathrm{Ni}_{20} \mathrm{Bi}_{40} / \mathrm{C}$ ) are slightly lower (Tables S4-S6, S8 and S10 in the ESM) and their $d$-spacing values and lattice parameters (Table 2) are slightly higher than for the $\mathrm{Pd} / \mathrm{C}$ catalyst (Table S3 in the ESM), which indicates that the $\mathrm{Pd}$ lattice expands and is modified by alloying with $\mathrm{Ni}$ and $\mathrm{Bi}$. This statement is confirmed by various research groups $[2,7,9,12$, $44,45]$. The determined inter-planar spacing for the catalysts in the recorded HRTEM micrographs (Figs. 1(e)-1(h) and Figs. S2(e)-2(h) in the ESM) conforms to the XRD results (Table 2).

Furthermore, the XRD pattern of the $\mathrm{Pd}_{60} \mathrm{Ni}_{40} / \mathrm{C}$ catalyst has additional diffraction peaks approx. at $41^{\circ}, 48^{\circ}, 70^{\circ}, 84^{\circ}$ and $89^{\circ}$ close to the diffraction peaks of $\mathrm{Pd}$ fcc crystalline structure, which is assigned to an alloying compound with a crystalline structure of $\mathrm{Pd}_{09} \mathrm{Ni}_{08} \_106936$-ICSD with the same miller indices (Fig. 2).

The XRD patterns of $\mathrm{Pd}_{60} \mathrm{Bi}_{40} / \mathrm{C}, \mathrm{Pd}_{60} \mathrm{Ni}_{20} \mathrm{Bi}_{20} / \mathrm{C}, \mathrm{Pd}_{80} \mathrm{Ni}_{10} \mathrm{Bi}_{10} / \mathrm{C}$ and $\mathrm{Pd}_{40} \mathrm{Ni}_{20} \mathrm{Bi}_{40} / \mathrm{C}$ catalysts also reveal additional diffraction peaks approx. at $24^{\circ}, 30^{\circ}$, and $33^{\circ}$ and were identified as crystalline structure of $\mathrm{Bi}_{2} \mathrm{O}_{2}\left(\mathrm{CO}_{3}\right)_{2} 252588$-ICSD (Fig. 2 and Fig. S8 in the ESM).

The diffraction peak located at $27^{\circ}$ is assigned to the crystalline structure of $\mathrm{Bi}$ 53797-ICSD with the miller indices of (210) for the

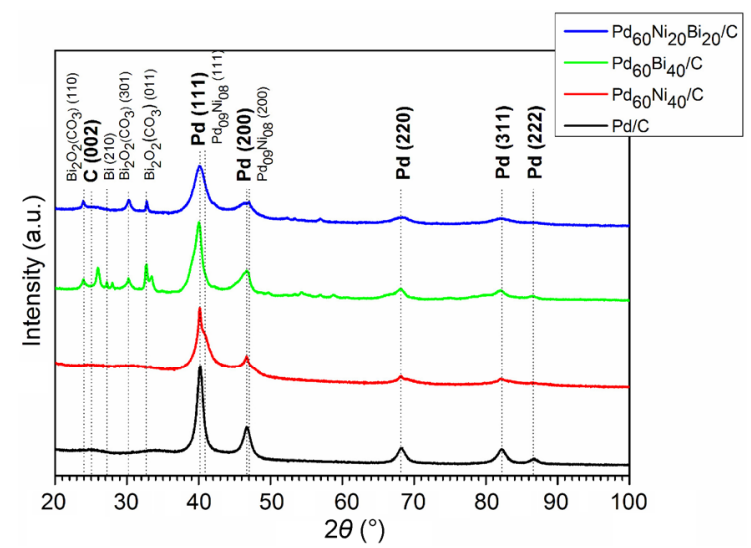

Figure 2 XRD patterns of carbon supported Pd-based nanocatalysts. 
Table 2 Structure analysis of carbon supported Pd-based catalysts by XRD

\begin{tabular}{|c|c|c|c|}
\hline Catalysts & $\begin{array}{c}d \text {-spacing Pd } \\
(111)(\mathrm{nm})\end{array}$ & $\begin{array}{l}\text { Lattice parameter } \\
\qquad(\mathrm{nm})\end{array}$ & $\begin{array}{l}\text { Crystallite size } \\
\text { (nm) }\end{array}$ \\
\hline $\mathrm{Pd} / \mathrm{C}$ & 0.2244 & Pd: $a=0.3891$ & Pd: 9 \\
\hline $\mathrm{Pd}_{60} \mathrm{Ni}_{40} / \mathrm{C}$ & 0.2245 & $\begin{array}{l}\text { Pd: } a=0.3904 \\
\text { Pd }_{09} \mathrm{Ni}_{08}: a=0.3816\end{array}$ & $\begin{array}{c}\text { Pd: 6-12 } \\
\text { Pd }_{09} \mathrm{Ni}_{08}: 9\end{array}$ \\
\hline $\mathrm{Pd}_{60} \mathrm{Bi}_{40} / \mathrm{C}$ & 0.2259 & $\begin{array}{l}\text { Pd: } a=0.3904 \\
\text { PdBi_tetrag: } a=0.4567 ; \\
b=0.726 ; c=1.068\end{array}$ & $\begin{array}{c}\text { Pd: } 9 \\
\text { PdBi_tetrag: } 10\end{array}$ \\
\hline $\mathrm{Pd}_{60} \mathrm{Ni}_{20} \mathrm{Bi}_{20} / \mathrm{C}$ & 0.2247 & $\begin{array}{l}\mathrm{Pd}: a=0.3894 \\
\mathrm{Bi}_{2} \mathrm{O}_{2}\left(\mathrm{CO}_{3}\right): a=0.385 \\
b=0.388 ; c=1.3750\end{array}$ & $\begin{array}{c}\text { Pd: } 5 \\
\mathrm{Bi}_{2} \mathrm{O}_{2}\left(\mathrm{CO}_{3}\right):>10\end{array}$ \\
\hline $\mathrm{Pd}_{70} \mathrm{Ni}_{25} \mathrm{Bi}_{5} / \mathrm{C}$ & 0.2230 & $\mathrm{Pd}: a=0.3863$ & Pd: 4 \\
\hline $\mathrm{Pd}_{70} \mathrm{Ni}_{20} \mathrm{Bi}_{10} / \mathrm{C}$ & 0.2247 & Pd: $a=0.3892$ & Pd: 4 \\
\hline $\mathrm{Pd}_{80} \mathrm{Ni}_{10} \mathrm{Bi}_{10} / \mathrm{C}$ & 0.2229 & Pd: $a=0.3894$ & Pd: 5 \\
\hline $\mathrm{Pd}_{40} \mathrm{Ni}_{20} \mathrm{Bi}_{40} / \mathrm{C}$ & 0.2248 & $\mathrm{Pd}: a=0.3894$ & $\mathrm{Pd}: 5 ; \mathrm{Bi}_{2} \mathrm{O}_{2}\left(\mathrm{CO}_{3}\right): 8$ \\
\hline
\end{tabular}

$\mathrm{Pd}_{60} \mathrm{Bi}_{40} / \mathrm{C}$ catalyst (Fig. 2). Also, tetragonal PdBi alloy (PdBi_tetrag 56279-ICSD) is one of the main constituents of this catalyst (Table S5 in the ESM).

The XRD patterns of $\mathrm{Pd}_{40} \mathrm{Ni}_{20} \mathrm{Bi}_{40} / \mathrm{C}$ and $\mathrm{Pd}_{60} \mathrm{Bi}_{40} / \mathrm{C}$ catalysts exhibit a diffraction peak approx. at $28^{\circ}$, which is attributed to the crystalline structure of $\mathrm{Bi}_{2} \mathrm{O}_{3}$ _beta_189995-ICSD with the miller indices of (120) (Fig. S8, Tables S5 and S10 in the ESM). More details about XRD data with Rietveld-refinement for the carbon supported Pd-based catalysts are given in Tables S3-S10 in the ESM.

The crystallite sizes of $\mathrm{Pd}$ and the alloyed compounds in the catalysts ( $\mathrm{Pd} / \mathrm{C}, \mathrm{Pd}_{60} \mathrm{Ni}_{40} / \mathrm{C}, \mathrm{Pd}_{60} \mathrm{Bi}_{40} / \mathrm{C}$ and $\mathrm{Pd}_{x} \mathrm{Ni}_{y} \mathrm{Bi}_{z} / \mathrm{C}$ ) were experimentally estimated in accordance with the Scherrer equation, assuming spherical crystallites. The crystallites are in the order of 4 to $12 \mathrm{~nm}$ (Table 2).

XPS was used to investigate the surface oxidation states, chemical compositions and binding energies of $\mathrm{Pd}, \mathrm{Ni}$ and $\mathrm{Bi}$ in all synthesized catalysts. The recorded XPS spectra of $\mathrm{Pd} / \mathrm{C}, \mathrm{Pd}_{60} \mathrm{Ni}_{40} / \mathrm{C}, \mathrm{Pd}_{60} \mathrm{Bi}_{40} / \mathrm{C}$ and the various $\mathrm{Pd}_{x} \mathrm{Ni}_{y} \mathrm{Bi}_{z} / \mathrm{C}$ catalysts show different oxidation states for their elements (Fig. 3 and Fig. S9 in the ESM).

As expected, the XPS results relating to the atomic content determinations in the bi- and ternary carbon supported Pd-based catalysts have a discrepancy to ICP-OES analysis due to predominant overlapping of $\mathrm{Pd}$ and $\mathrm{Bi}$ on $\mathrm{Ni}$ at the catalyst surface leading to lower Ni content (Tables S11 and S12 in the ESM and detailed in Tables S13-S20 in the ESM: deconvolution results of the elements).

The doublets of $\mathrm{Pd} 3 \mathrm{~d}_{3 / 2}$ and $\mathrm{Pd} 3 \mathrm{~d}_{5 / 2}$ peaks are attributed to $\mathrm{Pd}^{0}$ $(\rightarrow$ metallic $\mathrm{Pd})$ and $\mathrm{Pd}^{\mathrm{II}}$ species $(\rightarrow \mathrm{PdO})$ on the surface of all catalysts (Figs. 3(a)-3(d) and Figs. S9(a)-S9(d) in the ESM) according to Su et al., Wang et al. and Simões et al. $[9,12,46]$. It is observed that the binding energy of the $3 \mathrm{~d}_{5 / 2}$ peak of $\mathrm{PdO}$ for the $\mathrm{Ni}$ and $\mathrm{Bi}$ containing $\mathrm{Pd}$ catalysts shifts negatively compared to $\mathrm{Pd} / \mathrm{C}$ catalyst (Tables S11 and S12 in the ESM and detailed in Tables S13-S20 in the ESM). Wang et al. explain this issue by a down-shift of the d-band center of Pd i.e. the down-shift of the core-level of Pd to the Fermi level of Pd due to alloying with oxophilic elements which enhance its ethanol reaction intermediate tolerance resulting in a weak-interaction with the active sites of the catalyst (see electrochemical characterization results in Figs. 4(d), 4(h) and 4(l)) [9, 47].

Furthermore, the decrease of $\mathrm{Pd}^{\mathrm{II}}$ binding energies of 335.81 , 336.14, 335.95, 335.8, 335.86, 335.72 and $335.93 \mathrm{eV}$ for $\mathrm{Pd}_{60} \mathrm{Ni}_{40} / \mathrm{C}$, $\mathrm{Pd}_{60} \mathrm{Bi}_{40} / \mathrm{C}, \mathrm{Pd}_{60} \mathrm{Ni}_{20} \mathrm{Bi}_{20} / \mathrm{C}, \mathrm{Pd}_{75} \mathrm{Ni}_{20} \mathrm{Bi}_{5} / \mathrm{C}, \mathrm{Pd}_{70} \mathrm{Ni}_{20} \mathrm{Bi}_{10} / \mathrm{C}, \mathrm{Pd}_{80} \mathrm{Ni}_{10} \mathrm{Bi}_{10} / \mathrm{C}$ and $\mathrm{Pd}_{40} \mathrm{Ni}_{20} \mathrm{Bi}_{40} / \mathrm{C}$ catalysts compared to the $\mathrm{Pd}^{\mathrm{II}}$ binding energy of $336.27 \mathrm{eV}$ for $\mathrm{Pd} / \mathrm{C}$ catalyst suggests a suppression of the $\mathrm{PdO}$ formation due to alloying with $\mathrm{Ni}$ and $\mathrm{Bi}$ on the surface of bi- and ternary Pd-based catalysts as reported by Su et al. (Tables S11 and S12 in the ESM and detailed in Tables S13-S20 in the ESM) [12].

Figures $3(\mathrm{e})$ and $3(\mathrm{f})$ show the doublets of $\mathrm{Ni} 2 \mathrm{p}_{1 / 2}$ and $\mathrm{Ni} 2 \mathrm{p}_{3 / 2}$ which assigned to $\mathrm{Ni}^{\mathrm{II}}$ species such as $\mathrm{NiO}$ and $\mathrm{Ni}(\mathrm{OH})_{2}$ can be formed on the catalyst surfaces of $\mathrm{Pd}_{60} \mathrm{Ni}_{40} / \mathrm{C}$ and $\mathrm{Pd}_{60} \mathrm{Ni}_{20} \mathrm{Bi}_{20} / \mathrm{C}$ according to Wang et al. [9]. The Ni 2p XPS spectra of the $\mathrm{Pd}_{75} \mathrm{Ni}_{20} \mathrm{Bi}_{5} / \mathrm{C}$, $\mathrm{Pd}_{70} \mathrm{Ni}_{20} \mathrm{Bi}_{10} / \mathrm{C}, \mathrm{Pd}_{80} \mathrm{Ni}_{10} \mathrm{Bi}_{10} / \mathrm{C}$ and $\mathrm{Pd}_{40} \mathrm{Ni}_{20} \mathrm{Bi}_{40} / \mathrm{C}$ catalysts show that in the doublets of $\mathrm{Ni} 2 \mathrm{p}_{1 / 2}$ and $\mathrm{Ni} 2 \mathrm{p}_{3 / 2}$ only one $\mathrm{Ni}^{\mathrm{II}}$ species is observed which is attributable to $\mathrm{NiO}$ (Figs. S9(e)-S9(h) in the ESM) compared to the XPS results of the $\mathrm{Pd}_{60} \mathrm{Ni}_{20} \mathrm{Bi}_{20} / \mathrm{C}$ and $\mathrm{Pd}_{60} \mathrm{Ni}_{40} / \mathrm{C}$ catalysts where $\mathrm{Ni}(\mathrm{OH})_{2}$ as the second $\mathrm{Ni}^{\mathrm{II}}$ species was identified. The measured values of the Ni $2 p$ XPS spectra for all catalysts are undefined (Figs. 3(e) and 3(f) and Figs. S9(e)-S9(h) in the ESM)most likely due to the inhomogeneous distribution of the metal nanoparticles on the carbon support material (see TEM-EDX results: Figs. S3-S7 in the ESM).

The surface of the $\mathrm{Pd}_{80} \mathrm{Ni}_{10} \mathrm{Bi}_{10} / \mathrm{C}$ catalyst contains the most oxide species of Pd, Ni and Bi (Tables S11, S12 and S19 in the ESM), but limits its catalytic activity for the alkaline EOR (Fig. 4(k)). The presence of the lower $\mathrm{Ni}$ oxide content (lower electron and proton conductivity) of the $\mathrm{Pd}_{80} \mathrm{Ni}_{10} \mathrm{Bi}_{10} / \mathrm{C}$ catalyst is the main limiting factor for its lower EOR activity compared to the other catalysts (Tables S11 and S12 in the ESM and detailed in Tables S13-S20 in the ESM). It has been shown literature that $\mathrm{Ni}$ oxide promotes significantly the EOR performance of the catalysts used $[4,16]$.

The doublets of $\mathrm{Bi} 4 \mathrm{f}_{5 / 2}$ and $\mathrm{Bi} 4 \mathrm{f}_{7 / 2}$ peaks (Fig. $3(\mathrm{~g})$ ) for the $\mathrm{Pd}_{60} \mathrm{Bi}_{40} / \mathrm{C}$ catalyst can be attributed to $\mathrm{Bi}^{0}$ and $\mathrm{Bi}^{\mathrm{III}}$ species such as metallic
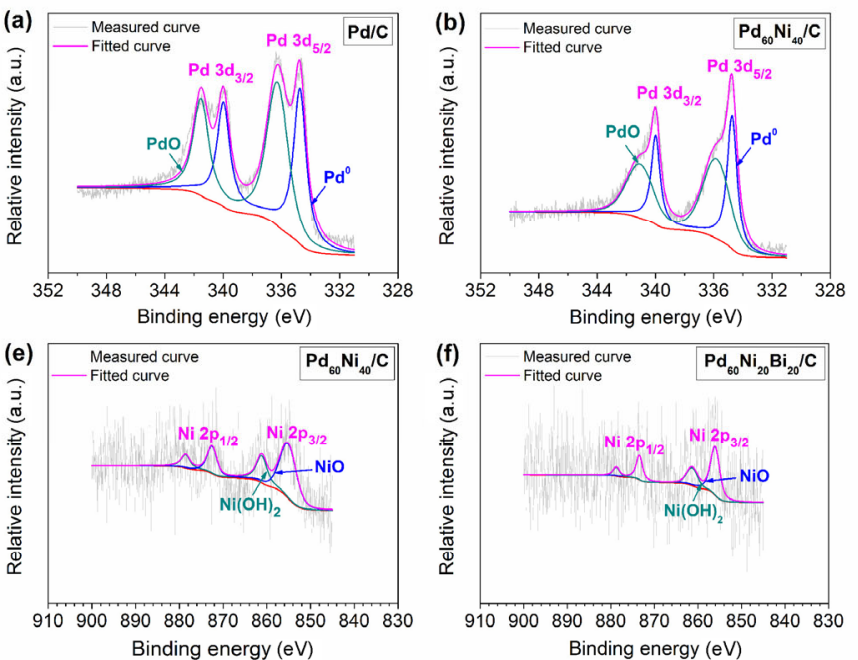
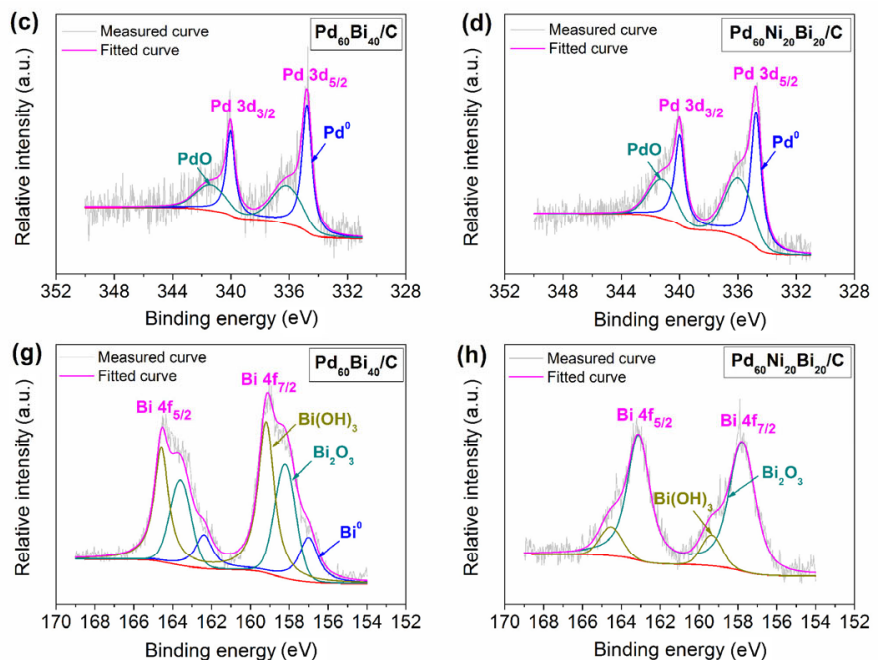

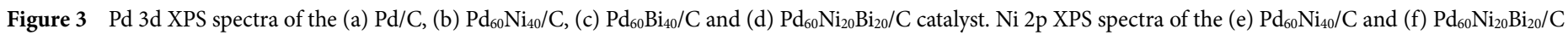
catalyst. Bi $4 f$ XPS spectra of the (g) $\mathrm{Pd}_{60} \mathrm{Bi}_{40} / \mathrm{C}$ and (h) $\mathrm{Pd}_{60} \mathrm{Ni}_{20} \mathrm{Bi}_{20} / \mathrm{C}$ catalyst. 

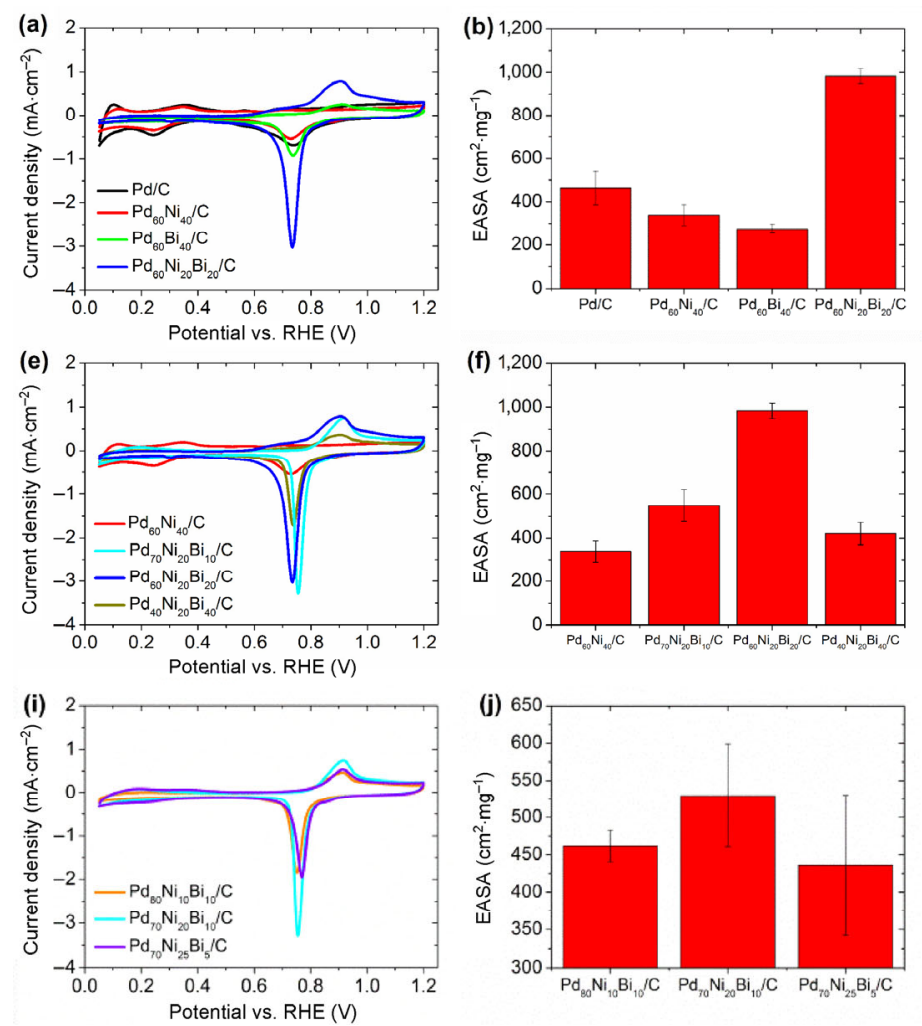
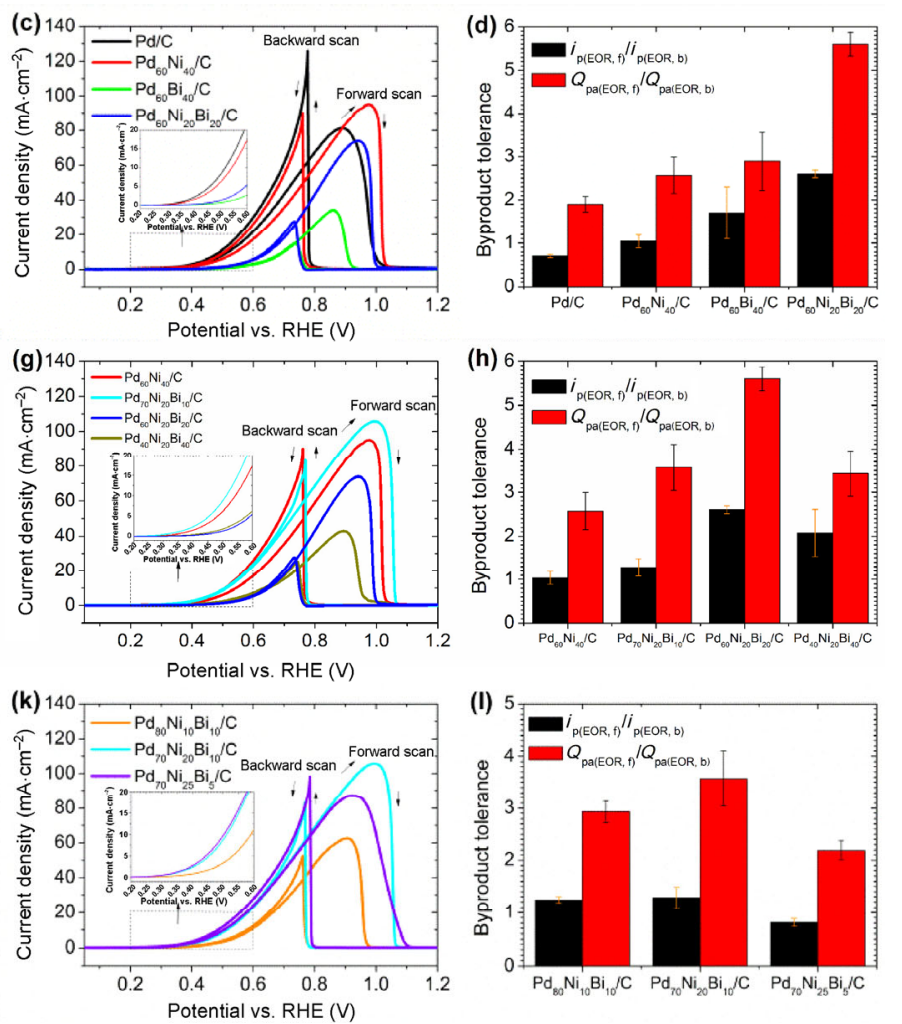

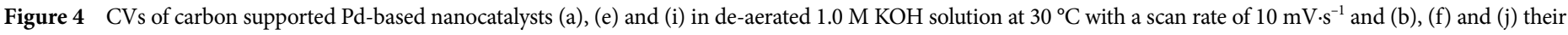

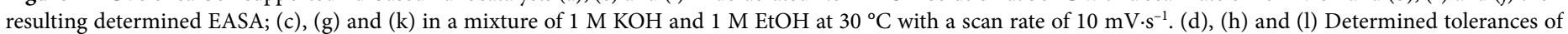
Pd-based nanocatalysts toward ethanol reaction intermediates using the EOR measurements.

$\mathrm{Bi}, \mathrm{Bi}_{2} \mathrm{O}_{3}$ and $\mathrm{Bi}(\mathrm{OH})_{3}$ located at $157,158.21$ and $159.19 \mathrm{eV}$ [46]. Metallic $\mathrm{Bi}$ and $\mathrm{Bi}_{2} \mathrm{O}_{3}$ species were also identified by XRD (Table S5 in the $\mathrm{ESM}$ ) in $\mathrm{Pd}_{60} \mathrm{Bi}_{40} / \mathrm{C}$ catalyst, which confirmed the XPS results. By contrast, the doublets of $\mathrm{Bi} 4 \mathrm{f}_{5 / 2}$ and $\mathrm{Bi} 4 \mathrm{f}_{7 / 2}$ peaks (Fig. 3(h)) for the $\mathrm{Pd}_{60} \mathrm{Ni}_{20} \mathrm{Bi}_{20} / \mathrm{C}$ catalyst are attributed to $\mathrm{Bi}_{2} \mathrm{O}_{3}$ and $\mathrm{Bi}(\mathrm{OH})_{3}$ located at 157.78 and $159.35 \mathrm{eV}$ [46]. It is assumed that no complete reduction of $\mathrm{Bi}$ oxide species to $\mathrm{Bi}$ has occurred for the synthesis of the $\mathrm{Pd}_{60} \mathrm{Ni}_{20} \mathrm{Bi}_{20} / \mathrm{C}$ catalyst because the $\mathrm{Bi}$ peak $\left(\mathrm{Bi}^{0}\right)$ in the XPS spectrum of $\mathrm{Pd}_{60} \mathrm{Ni}_{20} \mathrm{Bi}_{20} / \mathrm{C}$ catalyst is absent (Fig. 3(h)) compared to the XPS spectrum of $\mathrm{Pd}_{60} \mathrm{Bi}_{40} / \mathrm{C}$ catalyst, which conforms to the XRD results (Table $\mathrm{S} 5$ in the ESM).

The resulting Bi $4 \mathrm{f} \mathrm{XPS} \mathrm{spectra} \mathrm{show} \mathrm{that} \mathrm{metallic} \mathrm{Bi}$ and $\mathrm{Bi}$ oxide species are distributed on the surfaces of $\mathrm{Pd}_{70} \mathrm{Ni}_{25} \mathrm{Bi}_{5} / \mathrm{C}, \mathrm{Pd}_{70} \mathrm{Ni}_{20} \mathrm{Bi}_{10} / \mathrm{C}$ and $\mathrm{Pd}_{40} \mathrm{Ni}_{20} \mathrm{Bi}_{40} / \mathrm{C}$ catalysts (Figs. S9(i), S9(j), and $\mathrm{S} 9(\mathrm{l})$ in the ESM). It can be observed, however, that the doublets of $\mathrm{Bi} 4 \mathrm{f}_{5 / 2}$ and $\mathrm{Bi} 4 \mathrm{f}_{7 / 2}$ peaks from the $\mathrm{Pd}_{80} \mathrm{Ni}_{10} \mathrm{Bi}_{10} / \mathrm{C}$ catalyst shift by more than $1 \mathrm{eV}$ to higher binding energies, due to the increased measured oxygen content compared to the other catalysts (Figs. S9(i)-S9(k) and Tables S11, S12, S17-S20 in the ESM) and the peak of metallic $\mathrm{Bi}$ is absent. The explanation for the absence of $\mathrm{Bi}$ peak is already commented previously. An additional $\mathrm{Bi}$ oxide species on the $\mathrm{Pd}_{80} \mathrm{Ni}_{10} \mathrm{Bi}_{10} / \mathrm{C}$ catalyst surface, such as $\mathrm{Bi}(\mathrm{OH})_{3}$, was identified (Fig. S9(k) in the ESM) as in $\mathrm{Pd}_{60} \mathrm{Bi}_{40} / \mathrm{C}$ and $\mathrm{Pd}_{60} \mathrm{Ni}_{20} \mathrm{Bi}_{20} / \mathrm{C}$ catalysts (Figs. 3(g) and 3(h)) [46]. Furthermore, the XPS spectra obtained for $\mathrm{C}$ and $\mathrm{O}$ are demonstrated in the ESM (Figs. S10 and S11 in the ESM; additional information about XPS analysis).

Subsequently, the results of the physico-chemical characterization will be used to interpret the electrochemical characterization results of all Pd-based electrocatalysts.

\subsection{Electrochemical characterization}

\subsubsection{Optimum catalyst ink preparation procedure}

The catalyst ink preparation plays an important role for a homogeneous distribution on the glassy carbon substrate of RDE to obtain reproducible results for electrochemical characterization. The addition of Nafion ionomer as binder shows according to Shinozaki et al. a better quality of catalyst dispersion than is the case without Nafion ionomer in the context of the reproducibility of the electrochemical active surface area (EASA), mass activity and the specific mass activity determinations of the catalyst in RDE measurements [48]. The research group has found that the optimal dispersion of catalyst particles was obtained if the Nafion ionomer with a concentration of $24 \mathrm{wt}$.\% is used. Furthermore, it was stated that the temperature of the catalyst slurry increased while sonication whereby the EASA decreased due to thermally induced degradation of smaller catalyst particles. This temperature increase can be counteracted by cooling of the catalyst slurry using an ice-water bath during the sonication process [48].

Pollet and co-workers investigated the effect of the sonication parameters used in the distribution of catalyst inks based on $\mathrm{Pt}$ nanoparticles with Nafion ionomer as binder [49]. The frequency and power of the sonication bath or probe significantly influence the EASA, shown in a comparison of two samples with different sonication times, the one sonicated for $120 \mathrm{~min}$ thus results in a EASA decline of $45 \%$ compared to the other sonicated for $30 \mathrm{~min}$. It was also reported that the Nafion ionomer separated from the $\mathrm{Pt}$ nanoparticles which then also agglomerated and dissolved by longer sonication time [49].

The aforementioned studies concerning the effects of Nafion binder and the sonication parameters on the catalyst ink preparation and catalyst distribution on the RDE were also considered in our experiments (see Experimental Section 2.4) and improvements were implemented. In this context we have thus developed an optimum catalyst ink preparation procedure resulting in a homogeneous catalyst ink and homogeneous catalyst distribution on the RDE for reproducible results, respectively. 


\subsubsection{Ni and Bi effects on EOR performance of $P d / C$ catalysts}

CVs of $\mathrm{Pd} / \mathrm{C}, \mathrm{Pd}_{60} \mathrm{Ni}_{40} / \mathrm{C}, \mathrm{Pd}_{60} \mathrm{Bi}_{40} / \mathrm{C}$ and $\mathrm{Pd}_{60} \mathrm{Ni}_{20} \mathrm{Bi}_{20} / \mathrm{C}$ catalysts were recorded stationary (without rotation) in a de-aerated $1.0 \mathrm{M}$ $\mathrm{KOH}$ electrolyte at $30{ }^{\circ} \mathrm{C}$ in a potential range of 0.05-1.2 V (Fig. 4(a)). By the presence of $\mathrm{Bi}$ in carbon supported Pd electrocatalysts, the hydrogen adsorption/and absorption region $(0.05-0.5 \mathrm{~V})$ in the anodic scan and cathodic scan of the CVs of $\mathrm{Pd}_{60} \mathrm{Bi}_{40} / \mathrm{C}$ and $\mathrm{Pd}_{60} \mathrm{Ni}_{20} \mathrm{Bi}_{20} / \mathrm{C}$ is drastically reduced (no distinct visible characteristic peaks) compared to the $\mathrm{CVs}$ of $\mathrm{Pd} / \mathrm{C}$ and $\mathrm{Pd}_{60} \mathrm{Ni}_{40} / \mathrm{C}$ electrocatalysts (Fig. 4(a)). Neto et al. show the same effect of $\mathrm{Bi}$ in $\mathrm{CVs}$ of $\mathrm{Pd}_{x} \mathrm{Bi}_{y} / \mathrm{C}$ catalysts in various atomic ratios [7]. Simões et al. confirm the suppression of the hydrogen adsorption/absorption processes by $\mathrm{Bi}$ on $\mathrm{Pd}$ and $\mathrm{Pt}$ containing Bi catalysts compared to monometallic $\mathrm{Pd} / \mathrm{C}$ and $\mathrm{Pt} / \mathrm{C}$ catalysts [46]. This suppression depends on the height of the amount of $\mathrm{Bi}$ atoms which are covered on the surface of the $\mathrm{Pd}$ catalyst and have strong interaction with Pd [46].

Furthermore, another distinctive peak in the anodic scan for the Bi containing catalysts appears at approx. 0.9 V (Fig. 4(a)), which attributed to $\mathrm{Bi}_{2} \mathrm{O}_{3}$ species from the reaction of $\mathrm{Bi}$ in the presence of an alkaline solution [50]. The Bi oxide species were also identified by XRD (Tables S5 and S6 in the ESM). The oxidation of $\mathrm{Bi}$ in $\mathrm{KOH}$ electrolyte starts at approx. $0.5 \mathrm{~V}$ to $\mathrm{Bi}(\mathrm{OH})_{3}$ as a non-soluble compound, identified in the $\mathrm{Bi}_{2} \mathrm{O}_{3}$ phase according to Simões et al. (Fig. 4(a)) [46].

The reduction current peak in the cathodic scan between the potential of 0.5 and $0.9 \mathrm{~V}$ can be attributed to the formation of Pd and/or Bi oxide species in the study synthesized catalysts (Figs. 4(a), $4(\mathrm{e})$ and $4(\mathrm{i}))[7,13]$. By integration of the reduction peak (PdO to $\mathrm{Pd} \rightarrow$ catalyst charge $\mathrm{Q}_{\mathrm{Pd}}$ ) with the Echem AnalystTM SoftwareGamry, the charge was determined to calculate the EASA of each catalyst according to Eq. (2).

$$
\mathrm{EASA}=\frac{Q_{\mathrm{Pd}}}{Q_{\mathrm{Pd}}^{*}}\left(\frac{1}{c_{\mathrm{L}}}\right)\left(\frac{1}{A_{\mathrm{GC}}}\right)
$$

The calculated EASAs (incl. standard deviation) of all catalysts using the parameters (Eq. (2)) such as $Q^{*}{ }_{\mathrm{Pd}}$ (= reduction charge of $405 \mu \mathrm{C} \cdot \mathrm{cm}^{-2}$ of $\mathrm{PdO}$ to $\mathrm{Pd}$, assumed value according to Jongsomjit et al. [29]), $c_{\mathrm{L}}$ (= catalyst loading of $56 \mu \mathrm{g}_{\mathrm{Pd}} \cdot \mathrm{cm}^{-2}$ on the RDE) and the $A_{\mathrm{GC}}$ (= surface area of $0.196 \mathrm{~cm}^{2}$ from the glassy carbon substrate (GC) on RDE) are demonstrated in Figs. 4(b), 4(f) and 4(j) [13]. The charge of the reduction of $\mathrm{Bi}$ oxide to $\mathrm{Bi}$ could not be considered for the EASA calculation of the Bi containing catalysts because the $\mathrm{Bi}$ oxide reduction arises in the same potential range as the $\mathrm{Pd}$ oxide reduction. Therefore, the excellent EASA result of the $\mathrm{Pd}_{60} \mathrm{Ni}_{20} \mathrm{Bi}_{20} / \mathrm{C}$ catalyst compared to the other carbon supported Pd-based electrocatalysts (Fig. 4(b) and Table 3 ) is only comparable with the $\mathrm{Pd}_{60} \mathrm{Bi}_{40} / \mathrm{C}$ catalysts. The $\mathrm{Pd}_{60} \mathrm{Ni}_{20} \mathrm{Bi}_{20} / \mathrm{C}$ catalyst with a 2.6-fold higher EASA than the $\mathrm{Pd}_{60} \mathrm{Bi}_{40} / \mathrm{C}$ catalyst depends on the Bi content. Neto et al. report that the increased addition of $\mathrm{Bi}$ to $\mathrm{Pd}$ catalysts causes more agglomerations whereby the active sites of $\mathrm{Pd}$ are blocked resulting in decreasing of the EASA (Fig. 4(b)) and consequently the catalytic activity (Fig. 4(c)) [7].

Additionally, $\mathrm{Pd}_{60} \mathrm{Ni}_{40} / \mathrm{C}$ and $\mathrm{Pd}_{60} \mathrm{Ni}_{20} \mathrm{Bi}_{20} / \mathrm{C}$ catalysts were investigated under the same measurement conditions in Fig. S12(a) in the ESM, but using the potential range of $0.05-1.5 \mathrm{~V}$ to find out if $\mathrm{Ni}$ is present in the catalysts. Figure S12(b) in the ESM shows that the peak in the anodic scan at the potential range of $1.3-1.5 \mathrm{~V}$ as the oxidation of $\mathrm{Ni}(\mathrm{OH})_{2}$ to $\mathrm{NiOOH}$ whereas the peak in the cathodic scan at the potential range of $1.2-1.4 \mathrm{~V}$ as the reduction of $\mathrm{NiOOH}$ to $\mathrm{Ni}(\mathrm{OH})_{2}$ are represented for both catalysts $\mathrm{Pd}_{60} \mathrm{Ni}_{40} / \mathrm{C}$ and $\mathrm{Pd}_{60} \mathrm{Ni}_{20} \mathrm{Bi}_{20} / \mathrm{C}$ according to Zhang et al. [2]. It is evident and also as expected that the current density of the $\mathrm{Ni}$ oxidation and reduction peaks of $\mathrm{Pd}_{60} \mathrm{Ni}_{40} / \mathrm{C}$ catalyst are higher than for the $\mathrm{Pd}_{60} \mathrm{Ni}_{20} \mathrm{Bi}_{20} / \mathrm{C}$ catalyst (Fig. S12 in the ESM).
The determination of the catalytic activity and stability toward EOR of $\mathrm{Pd} / \mathrm{C}, \mathrm{Pd}_{60} \mathrm{Ni}_{40} / \mathrm{C}, \mathrm{Pd}_{60} \mathrm{Bi}_{40} / \mathrm{C}$ and $\mathrm{Pd}_{60} \mathrm{Ni}_{20} \mathrm{Bi}_{20} / \mathrm{C}$ catalysts takes place in a mixture of $1 \mathrm{M} \mathrm{KOH}$ and $1 \mathrm{M} \mathrm{EtOH}$ by means of $\mathrm{CV}$ using $\mathrm{RDE}$ (without rotation) at $30^{\circ} \mathrm{C}$. The $\mathrm{Pd}_{60} \mathrm{Ni}_{40} / \mathrm{C}$ catalyst exhibits the best result relating to EOR activity compared to the other carbon supported Pd-based catalysts (Fig. 4(c) and Table 3).

Nickel as an additive is more oxophilic than $\mathrm{Bi}$ in the resulting low onset potential of $\mathrm{Pd}_{60} \mathrm{Ni}_{40} / \mathrm{C}$ catalyst with a high produced current density toward ethanol oxidation in alkaline medium compared to catalysts containing Bi (see small figure in Fig. 4(c) and Table 3) [51]. This means that $\mathrm{Ni}$ generates more adsorbed $\mathrm{OH}$ on the Pd catalyst surface than Bi to oxidize the adsorbed ethanol species quickly. Zhang et al. report that onset potentials of $\mathrm{Pd}_{x} \mathrm{Ni}_{y} / \mathrm{C}$ based catalysts toward ethanol oxidation depend significantly on the surface concentration of $\mathrm{Ni}$ [2].

Furthermore, in the synthesized Pd-based electrocatalysts $\mathrm{Bi}$ facilitates an essential improvement of the tolerance toward ethanol intermediates from the EOR in the electrolyte mixture of $1 \mathrm{M} \mathrm{KOH}$ and $1 \mathrm{M}$ EtOH (Fig. 4(d) and Table 3), but their onset potentials shift to higher potentials (see small figure in Fig. 4(c) and Table 3) and their catalytic activities decrease (Fig. 4(c) and Table 3 ) compared to $\mathrm{Pd} / \mathrm{C}$ and $\mathrm{Pd}_{60} \mathrm{Ni}_{40} / \mathrm{C}$ catalysts, respectively. The higher onset potential and the lower specific activity of the $\mathrm{Pd}_{60} \mathrm{Bi}_{40} / \mathrm{C}$ catalyst toward the ethanol oxidation compared to the $\mathrm{Pd}_{60} \mathrm{Ni}_{20} \mathrm{Bi}_{20} / \mathrm{C}$ catalyst (Fig. 4(c) and Table 3) are due to its higher Bi content thus formed Bi oxide species block multiple active sites of Pd [7].

The tolerance toward EOR intermediates was determined by two different methods (Figs. 4(d), 4(h) and 4(l)): 1) using the ratio of the peak current density of the forward $\left(i_{\mathrm{p}(\mathrm{EOR}, \mathrm{f})}\right)$ and backward scan $\left(i_{\mathrm{p}(\mathrm{EOR}, \mathrm{b})}\right)[12]$, and 2$)$ using the ratio of the integrated oxidation peak current density area (total charge) of forward $\left(Q_{\mathrm{pa}(\mathrm{EOR}, \mathrm{f})}\right)$ and backward scan $\left(Q_{\mathrm{pa}(\mathrm{EOR}, \mathrm{b})}\right)$ from EOR measurements in alkaline medium (Figs. 4(c), 4(g) and 4(k)), respectively [51]. Sekol et al. identified the second method as being a more accurate method than the first one for determining the catalyst tolerance toward reaction intermediates resulting from the EOR [51]. The higher the value the better is the tolerance of the catalyst toward the reaction intermediates of ethanol. This means that the ethanol reaction intermediates or poisonous species which are not oxidized in the forward scan, are oxidatively removed in the backward scan $[12,51]$.

Figure $4(\mathrm{~d})$ shows that the $\mathrm{Pd}_{60} \mathrm{Ni}_{20} \mathrm{Bi}_{20} / \mathrm{C}$ catalyst exhibits the best tolerance by far toward the reaction intermediates of ethanol compared to the other catalysts. The excellent results relating to the byproduct tolerance of the Bi containing catalysts can be explained by the study of Paschos et al. [52]. In a CO stripping test was stated that one Bi adatom blocked three Pd surface atoms for avoiding the poisoning of the Pd active sites in the BiPd-based catalyst [52].

It should be noted, the $i_{\mathrm{f}} / i_{\mathrm{b}}$ or $Q_{\mathrm{f}} / Q_{\mathrm{b}}$ ratio is not a sufficient but a necessary indicator for evaluation of anti-poisoning tolerance of a catalyst as it has been discussed in Refs. $[53,54]$.

After the $\mathrm{Pd} / \mathrm{C}, \mathrm{Pd}_{60} \mathrm{Ni}_{40} / \mathrm{C}, \mathrm{Pd}_{60} \mathrm{Bi}_{40} / \mathrm{C}$ and $\mathrm{Pd}_{60} \mathrm{Ni}_{20} \mathrm{Bi}_{20} / \mathrm{C}$ nanocatalysts were subjected to $1 \mathrm{~h}$ stress at an applied potential of $0.83 \mathrm{~V}$, the novel $\mathrm{Pd}_{60} \mathrm{Ni}_{20} \mathrm{Bi}_{20} / \mathrm{C}$ catalyst showed the best result in terms of electrocatalytic stability toward alkaline EOR (Fig. 5(a) and Table 3). The order of the decrease of produced current density in percentage of all catalysts from the start until to the end of CA measurement is given in Fig. 5(b). The decrease of current densities of all catalysts after $1 \mathrm{~h}$ stress is listed in following order: $\mathrm{Pd}_{60} \mathrm{Bi}_{40} / \mathrm{C}>\mathrm{Pd}_{60} \mathrm{Ni}_{40} / \mathrm{C}>$ $\mathrm{Pd} / \mathrm{C}>\mathrm{Pd}_{60} \mathrm{Ni}_{20} \mathrm{Bi}_{20} / \mathrm{C}$.

\subsubsection{Varying atomic ratios of $\mathrm{Pd}, \mathrm{Ni}$ and $\mathrm{Bi}$ in EOR catalysts}

Furthermore, the electrocatalytic activities and stabilities of the synthesized carbon supported $\mathrm{Pd}_{x} \mathrm{Ni}_{y} \mathrm{Bi}_{z}$ catalysts $\left(\mathrm{Pd}_{70} \mathrm{Ni}_{25} \mathrm{Bi}_{5} / \mathrm{C}\right.$, $\mathrm{Pd}_{70} \mathrm{Ni}_{20} \mathrm{Bi}_{10} / \mathrm{C}, \mathrm{Pd}_{80} \mathrm{Ni}_{10} \mathrm{Bi}_{10} / \mathrm{C}, \mathrm{Pd}_{40} \mathrm{Ni}_{20} \mathrm{Bi}_{40} / \mathrm{C}$ ) were characterized by $\mathrm{CV}$ and $\mathrm{CA}$ using the RDE in static mode with metal loading 
of $56 \mu \mathrm{g}_{\mathrm{Pd}} \cdot \mathrm{cm}^{-2}$ under same operating conditions (Figs. 4(e)-4(1)) as for $\mathrm{Pd} / \mathrm{C}, \mathrm{Pd}_{60} \mathrm{Ni}_{40} / \mathrm{C}, \mathrm{Pd}_{60} \mathrm{Bi}_{40} / \mathrm{C}$ and $\mathrm{Pd}_{60} \mathrm{Ni}_{20} \mathrm{Bi}_{20} / \mathrm{C}$ catalysts.

The influence of varied $\mathrm{Bi}$ content on the EOR performances of the synthesized catalysts $\mathrm{Pd}_{40} \mathrm{Ni}_{20} \mathrm{Bi}_{40} / \mathrm{C}$ and $\mathrm{Pd}_{70} \mathrm{Ni}_{20} \mathrm{Bi}_{10} / \mathrm{C}$ were investigated and compared to the benchmarks $\mathrm{Pd}_{60} \mathrm{Ni}_{40} / \mathrm{C}$ and $\mathrm{Pd}_{60} \mathrm{Ni}_{20} \mathrm{Bi}_{20} / \mathrm{C}$ (Figs. 4(e)-4(h)) which possessed the best catalytic performances in terms of alkaline EOR activity and stability (byproduct tolerance), respectively (Figs. 4(c)and 4(d)).

The recorded $\mathrm{CV}$ of the $\mathrm{Pd}_{70} \mathrm{Ni}_{20} \mathrm{Bi}_{10} / \mathrm{C}$ catalyst in de-aerated $1.0 \mathrm{M} \mathrm{KOH}$ shows a peak in the potential region between 0.1 and $0.2 \mathrm{~V}$ indicating an occurring hydrogen sorption reaction (Fig. 4(e)). It was confirmed that $\mathrm{Pd}_{x} \mathrm{Ni}_{y} \mathrm{Bi}_{z} / \mathrm{C}$ catalysts with more than 10 at.\% of $\mathrm{Bi}\left(\mathrm{Pd}_{60} \mathrm{Ni}_{20} \mathrm{Bi}_{20} / \mathrm{C}\right.$ and $\left.\mathrm{Pd}_{40} \mathrm{Ni}_{20} \mathrm{Bi}_{40} / \mathrm{C}\right)$ lead to a suppression of the hydrogen adsorption and the absorption process itself compared to the CVs of $\mathrm{Pd}_{60} \mathrm{Ni}_{40} / \mathrm{C}$ and $\mathrm{Pd}_{70} \mathrm{Ni}_{20} \mathrm{Bi}_{10} / \mathrm{C}$ catalysts (Fig. 4(e)). This effect was observed by adding a specific quantity of $\mathrm{Bi}$ to Pd as well as to Pt-based catalysts [7, 21, 46]. Neto et al. improved the alkaline EOR activities of carbon supported Pd catalysts by adding of decreased $\mathrm{Bi}$ contents [7], whereupon the $\mathrm{Pt}_{x} \mathrm{Bi}_{y}$ based catalysts were enhanced by increasing of Bi contents [21].

Further distinctive peaks in the potential regions of the anodic scan between 0.8 and $1.0 \mathrm{~V}$ and of the cathodic scan between 0.5 and $0.9 \mathrm{~V}$ are attributed to the oxidized and reduced $\mathrm{Bi}$ and $\mathrm{Pd}$ species, respectively (Fig. 4(e)). From the obtained XPS and XRD data we suggest that the peak around $0.9 \mathrm{~V}$ in the anodic scan (Figs. 4(e) and 4(i)) mainly originates from the oxidation of $\mathrm{Bi}$ and $\mathrm{Bi}$ oxide species. Simões et al. observed that this characteristic peak became higher in the CVs of carbon supported binary $\mathrm{Pd}_{x} \mathrm{Bi}_{y}$ catalysts by increasing of Bi content [46].

The former statement does not coincide with our RDE-CV measurements because this peak of $\mathrm{Pd}_{40} \mathrm{Ni}_{20} \mathrm{Bi}_{40} / \mathrm{C}$ is lower than for $\mathrm{Pd}_{60} \mathrm{Ni}_{20} \mathrm{Bi}_{20} / \mathrm{C}$ catalyst (Fig. 4(e)). Here, many cleaning cycles (= recorded CVs at a scan rate of $50 \mathrm{mV} \cdot \mathrm{s}^{-1}$ ) of the $\mathrm{Pd}_{40} \mathrm{Ni}_{20} \mathrm{Bi}_{40} / \mathrm{C}$ catalyst had to be conducted until a stable $\mathrm{CV}$ was obtained, because the peak, which was assigned to $\mathrm{Bi}$ oxide species, decreased with increased cycles. This decreased trend can be thus explained by the presence of impurities which undergo an oxidative removal or other species that are dissolved with increasing potential. As this phenomenon was also observed in the RDE-CV measurements of the $\mathrm{Pd}_{60} \mathrm{Bi}_{40} / \mathrm{C}$ catalyst. It is assumed that $\mathrm{Bi}^{0}$-agglomerates, mentioned by Simões et al., are oxidized and dissolved into the electrolyte [46].

Our studies are supported by the observation that the current densities in the EOR measurements of $\mathrm{Pd}_{60} \mathrm{Bi}_{40} / \mathrm{C}$ and $\mathrm{Pd}_{40} \mathrm{Ni}_{20} \mathrm{Bi}_{40} / \mathrm{C}$ catalysts increased when more cycles were performed. The proven $\mathrm{Bi}^{0}$-agglomerates in the $\mathrm{Pd}_{60} \mathrm{Bi}_{40} / \mathrm{C}$ which block the active sites of $\mathrm{Pd}$ are gradually dissolved and lead to higher activities after multiple $\mathrm{CV}$ cycles and it is assumed that this is also valid for the $\mathrm{Pd}_{40} \mathrm{Ni}_{20} \mathrm{Bi}_{40} / \mathrm{C}$ catalyst.

The study of Simões et al. reported that $\mathrm{Bi}^{0}$ agglomerates in catalysts with a Bi content as high as $20 \%$ or higher by EDX analysis. However, the agglomerations were not identified in carbon supported $\mathrm{Pd}_{x} \mathrm{Bi}_{y}$ catalysts with $\mathrm{Bi}$ content lower than $20 \%$ [46]. The prior statement cannot be confirmed by our TEM results (Figs. 1(c) and 1(d), and Figs. S1(c)-S1(h) and S2(a)-S2(d) in the ESM).

The $\mathrm{Pd}_{60} \mathrm{Ni}_{20} \mathrm{Bi}_{20} / \mathrm{C}$ catalyst as benchmark exhibits the highest EASA among all in this study synthesized carbon supported $\mathrm{Pd}_{x} \mathrm{Ni}_{y} \mathrm{Bi}_{z}$ catalysts, followed by $\mathrm{Pd}_{70} \mathrm{Ni}_{20} \mathrm{Bi}_{10} / \mathrm{C}$ catalyst (Table 3 and Fig. 4(f)). These results are conclusive in respect to the findings of Simões et al., that the reduction peak approx. at $0.75 \mathrm{~V}$ not only originates from $\mathrm{Pd}$ oxide species alone but also that other oxidized species are reduced in this region [46]. As more $\mathrm{Bi}$ is incorporated in the $\mathrm{Pd}_{60} \mathrm{Ni}_{20} \mathrm{Bi}_{20} / \mathrm{C}$ catalyst and more $\mathrm{Bi}$ species can be oxidized, the reduction peak approx. at $0.75 \mathrm{~V}$ in the cathodic sweep is also more distinct compared to $\mathrm{Pd}_{70} \mathrm{Ni}_{20} \mathrm{Bi}_{10} / \mathrm{C}$ catalyst (Fig. 4(e)).

The EASA of the $\mathrm{Pd}_{40} \mathrm{Ni}_{20} \mathrm{Bi}_{40} / \mathrm{C}$ is assumed to be lower due to the low Pd content and the high $\mathrm{Bi}$ content leading to agglomerations. The $\mathrm{Pd}_{70} \mathrm{Ni}_{20} \mathrm{Bi}_{10} / \mathrm{C}$ catalyst exceeded the alkaline EOR performance of $\mathrm{Pd}_{60} \mathrm{Ni}_{40} / \mathrm{C}$ in terms of peak current density and onset potential (Fig. 4(g) and Table 3). The onset potential for the alkaline EOR was decreased by $54 \mathrm{mV}$ using the $\mathrm{Pd}_{70} \mathrm{Ni}_{20} \mathrm{Bi}_{10} / \mathrm{C}$ and the peak current density could be increased by $10 \mathrm{~mA} \cdot \mathrm{cm}^{-2}$ compared to $\mathrm{Pd}_{60} \mathrm{Ni}_{40} / \mathrm{C}$ (Fig. 4(g) and Table 3). This result proves that small amounts of $\mathrm{Bi}$ in the carbon supported $\mathrm{Pd}_{x} \mathrm{Ni}_{y} \mathrm{Bi}_{z}$ catalyst enhance the activity and kinetics toward the EOR in an alkaline medium.

Even though $\mathrm{Pd}_{70} \mathrm{Ni}_{20} \mathrm{Bi}_{10} / \mathrm{C}$ catalyst shows the best results in respect to the onset potential and peak current density toward alkaline EOR (Table 3), the byproduct tolerance is not as good as for $\mathrm{Pd}_{60} \mathrm{Ni}_{20} \mathrm{Bi}_{20} / \mathrm{C}$ catalyst. However, $\mathrm{Pd}_{70} \mathrm{Ni}_{20} \mathrm{Bi}_{10} / \mathrm{C}$ is the second best catalyst among all of those tested if the total current for the calculation of the byproduct tolerance is used (Fig. 4(h) and Table 3). An explanation for this result could be that in the $\mathrm{Pd}_{60} \mathrm{Ni}_{20} \mathrm{Bi}_{20} / \mathrm{C}$ catalyst containing 20 at.\% of $\mathrm{Bi}$, more $\mathrm{Pd}$ active sites are protected by $\mathrm{Bi}$ atoms. However, the reactant is hindered from reaching the active sites leading to lower activity and higher stability than $\mathrm{Pd}_{70} \mathrm{Ni}_{20} \mathrm{Bi}_{10} / \mathrm{C}$ catalyst. By contrast, in the $\mathrm{Pd}_{70} \mathrm{Ni}_{20} \mathrm{Bi}_{10} / \mathrm{C}$ catalyst only 10 at.\% of $\mathrm{Bi}$ protects the active sites of $\mathrm{Pd}$ from poisoning resulting in a lower byproduct tolerance than for $\mathrm{Pd}_{60} \mathrm{Ni}_{20} \mathrm{Bi}_{20} / \mathrm{C}$ catalyst. However, the active sites are better accessible for ethanol and a higher EOR activity is observed in an alkaline medium (Fig. 4(h)).

The CA results of $\mathrm{Pd}_{70} \mathrm{Ni}_{20} \mathrm{Bi}_{10} / \mathrm{C}$ catalyst (Fig. 5(c)) correlate with the results obtained from the byproduct tolerance determinations (Fig. 4(h)). The $\mathrm{Pd}_{60} \mathrm{Ni}_{20} \mathrm{Bi}_{20} / \mathrm{C}$ catalyst, which exhibits the highest byproduct tolerance was also found to be the most stable one in the CA measurement followed by $\mathrm{Pd}_{70} \mathrm{Ni}_{20} \mathrm{Bi}_{10} / \mathrm{C}$, which still had almost $40 \%$ of the starting current density after $1 \mathrm{~h}$ at an applied potential of $0.83 \mathrm{~V}$ (Fig. 5(d) and Table 3).

Since the previous studies on the influence of $\mathrm{Ni}$ and $\mathrm{Bi}$ in carbon supported ternary $\mathrm{Pd}_{x} \mathrm{Ni}_{y} \mathrm{Bi}_{z}$ catalysts have shown that a low $\mathrm{Bi}$ content enhances the alkaline EOR activity of the catalyst, the attempt was
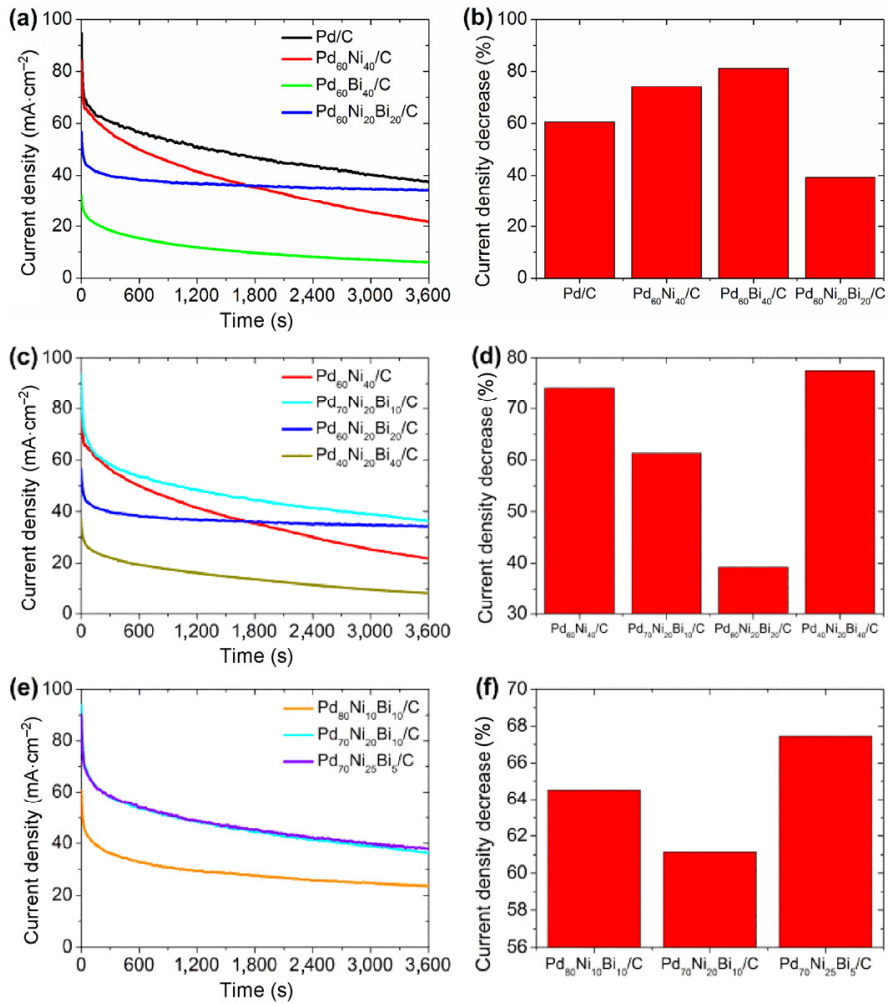

Figure 5 Stability tests of carbon supported Pd-based electrocatalysts (a), (c) and (e) in a mixture of $1 \mathrm{M} \mathrm{KOH}$ and $1 \mathrm{M} \mathrm{EtOH}$ at an applied potential of $0.83 \mathrm{~V}$ for 3,600 s using the CA method and (b), (d) and (f) their resulting current density decrease, given in percentage. 
Table 3 Electrochemical characterization results of all carbon supported Pd-based electrocatalysts

\begin{tabular}{|c|c|c|c|c|c|c|c|c|c|}
\hline Catalysts & $\begin{array}{c}\mathrm{EASA}^{\mathrm{a}} \\
\left(\mathrm{cm}^{2} \cdot \mathrm{mg}^{-1}\right)\end{array}$ & $\begin{array}{c}i_{\mathrm{f}}^{\mathrm{b}} \\
\left(\mathrm{mA} \cdot \mathrm{cm}^{-2}\right)\end{array}$ & $\begin{array}{c}\dot{i}_{\mathrm{b}}^{\mathrm{b}} \\
\left(\mathrm{mA} \cdot \mathrm{cm}^{-2}\right)\end{array}$ & $i_{\mathrm{f}} / i_{\mathrm{b}}^{\mathrm{c}}$ & $Q_{p a, f} / Q_{p a, b}{ }^{d}$ & $\begin{array}{c}E_{\text {onset }}{ }^{e} \\
(\mathrm{~V})\end{array}$ & $\begin{array}{c}i_{\text {Start }}{ }^{\mathrm{f}} \\
\left(\mathrm{mA} \cdot \mathrm{cm}^{-2}\right)\end{array}$ & $\begin{array}{c}i_{\text {End }}{ }^{f} \\
\left(\mathrm{~mA} \cdot \mathrm{cm}^{-2}\right)\end{array}$ & $\begin{array}{l}i_{\mathrm{D}^{g}} \\
(\%)\end{array}$ \\
\hline $\mathrm{Pd} / \mathrm{C}$ & $463 \pm 78$ & 81.17 & 125.95 & $0.70 \pm 0.04$ & $1.90 \pm 0.18$ & $0.280 \pm 0.015$ & 94.97 & 37.37 & 61 \\
\hline $\mathrm{Pd}_{60} \mathrm{Ni}_{40} / \mathrm{C}$ & $339 \pm 49$ & 95.11 & 90.05 & $1.04 \pm 0.15$ & $2.57 \pm 0.42$ & $0.290 \pm 0.018$ & 84.14 & 21.77 & 74 \\
\hline $\mathrm{Pd}_{60} \mathrm{Bi}_{40} / \mathrm{C}$ & $276 \pm 22$ & 34.03 & 14.96 & $1.70 \pm 0.60$ & $2.89 \pm 0.67$ & $0.352 \pm 0.015$ & 32.16 & 6.02 & 81 \\
\hline $\mathrm{Pd}_{60} \mathrm{Ni}_{20} \mathrm{Bi}_{20} / \mathrm{C}$ & $983 \pm 35$ & 73.93 & 27.60 & $2.60 \pm 0.09$ & $5.60 \pm 0.27$ & $0.348 \pm 0.007$ & 56.59 & 34.39 & 39 \\
\hline $\mathrm{Pd}_{70} \mathrm{Ni}_{25} \mathrm{Bi}_{5} / \mathrm{C}$ & $436 \pm 94$ & 87.28 & 98.19 & $0.81 \pm 0.07$ & $2.19 \pm 0.18$ & $0.239 \pm 0.009$ & 90.01 & 37.88 & 58 \\
\hline $\mathrm{Pd}_{70} \mathrm{Ni}_{20} \mathrm{Bi}_{10} / \mathrm{C}$ & $549 \pm 72$ & 105.77 & 83.39 & $1.28 \pm 0.20$ & $3.57 \pm 0.53$ & $0.236 \pm 0.005$ & 93.88 & 36.34 & 61 \\
\hline $\mathrm{Pd}_{80} \mathrm{Ni}_{10} \mathrm{Bi}_{10} / \mathrm{C}$ & $462 \pm 21$ & 62.55 & 52.30 & $1.24 \pm 0.06$ & $2.93 \pm 0.53$ & $0.274 \pm 0.008$ & 60.87 & 23.67 & 61 \\
\hline $\mathrm{Pd}_{40} \mathrm{Ni}_{20} \mathrm{Bi}_{40} / \mathrm{C}$ & $421 \pm 52$ & 42.79 & 25.37 & $2.07 \pm 0.54$ & $3.43 \pm 0.52$ & $0.323 \pm 0.033$ & 37.14 & 8.36 & 77 \\
\hline
\end{tabular}

${ }^{a}$ Electrochemical active surface area (EASA) determination; ${ }^{b} i_{\mathrm{f}}$ and $i_{\mathrm{b}}$ : peak current density of forward and backward scan; ${ }^{c} i_{\mathrm{f}} / i_{\mathrm{b}}$ : byproduct tolerance using peak current density of forward and backward scan; ${ }^{\mathrm{d}} Q_{\mathrm{pa}, f} / Q_{\mathrm{pa}, \mathrm{b}}$ : byproduct tolerance using the charge of the integrated peak current density area of the forward and backward scan; ${ }^{\mathrm{e}} E_{\text {onset: }}$ onset potential of the ethanol oxidation; ${ }^{\mathrm{f}} i_{\text {Start }}$ and $i_{\text {End: }}$ resulting current densities at an applied potential of $0.83 \mathrm{~V}$ after $0 \mathrm{~s}$ and $3,600 \mathrm{~s}$; ${ }^{\mathrm{g}} i_{\mathrm{D}}$ : loss of current density after stress test at an applied of $0.83 \mathrm{~V}$ for $3,600 \mathrm{~s}$.

made to decrease the Bi content even further than 10 at.\% to 5 at.\%. Additionally, the Pd content was increased to test whether the alkaline EOR activity would rise further with a higher Pd content. The catalysts $\mathrm{Pd}_{70} \mathrm{Ni}_{25} \mathrm{Bi}_{5} / \mathrm{C}$ and $\mathrm{Pd}_{80} \mathrm{Ni}_{10} \mathrm{Bi}_{10} / \mathrm{C}$ were therefore synthesized, electrochemically characterized and the obtained results were compared with $\mathrm{Pd}_{70} \mathrm{Ni}_{20} \mathrm{Bi}_{10} / \mathrm{C}$ catalyst (Figs. 4(i)-4(l), 5(e) and 5(f)).

In the EOR measurements, the $\mathrm{Pd}_{70} \mathrm{Ni}_{25} \mathrm{Bi}_{5} / \mathrm{C}$ and $\mathrm{Pd}_{80} \mathrm{Ni}_{10} \mathrm{Bi}_{10} / \mathrm{C}$ catalysts could not exceed the peak current density of the $\mathrm{Pd}_{70} \mathrm{Ni}_{20} \mathrm{Bi}_{10} / \mathrm{C}$ catalyst (Fig. 4(k)). However, $\mathrm{Pd}_{70} \mathrm{Ni}_{2} \mathrm{Bi}_{5} / \mathrm{C}$ has a low onset potential $\left(0.239 \mathrm{~V}\right.$ ), very close to that of $\mathrm{Pd}_{70} \mathrm{Ni}_{20} \mathrm{Bi}_{10} / \mathrm{C}(0.236 \mathrm{~V}$ ) (see small figure in Fig. 4(k) and Table 3). This supports the study that low amounts of Bi enhance the kinetics at the anode for the EOR in alkaline medium but the increase in peak current density could not be confirmed. The onset potential and the peak current density of the $\mathrm{Pd}_{80} \mathrm{Ni}_{10} \mathrm{Bi}_{10} / \mathrm{C}$ catalyst were both reduced compared to $\mathrm{Pd}_{70} \mathrm{Ni}_{20} \mathrm{Bi}_{10} / \mathrm{C}$ (Fig. 4(k)). This result is also conclusive when taking into account that the Ni content was reduced and the addition of higher amounts of $\mathrm{Ni}$ are necessary for a catalyst with high activity [2].

As expected, the byproduct tolerance of $\mathrm{Pd}_{70} \mathrm{Ni}_{25} \mathrm{Bi}_{5} / \mathrm{C}$ decreases when the Bi content is reduced from 10 at.\% to 5 at.\%. Also for the $\mathrm{Pd}_{80} \mathrm{Ni}_{10} \mathrm{Bi}_{10} / \mathrm{C}$ catalyst the byproduct tolerance is lower compared to $\mathrm{Pd}_{70} \mathrm{Ni}_{20} \mathrm{Bi}_{10} / \mathrm{C}$ but still higher than for $\mathrm{Pd}_{70} \mathrm{Ni}_{25} \mathrm{Bi}_{5} / \mathrm{C}$ (Fig. 4(l) and Table 3).

The CVs of the $\mathrm{Pd}_{70} \mathrm{Ni}_{2} \mathrm{Bi}_{5} / \mathrm{C}, \mathrm{Pd}_{80} \mathrm{Ni}_{10} \mathrm{Bi}_{1} / \mathrm{C}$ and $\mathrm{Pd}_{70} \mathrm{Ni}_{20} \mathrm{Bi}_{10} / \mathrm{C}$ catalysts exhibit similar curve progressions in $1.0 \mathrm{M} \mathrm{KOH}$ solution (Fig. 4(i)). The EASAs of $\mathrm{Pd}_{70} \mathrm{Ni}_{25} \mathrm{Bi}_{5} / \mathrm{C}$ and $\mathrm{Pd}_{80} \mathrm{Ni}_{10} \mathrm{Bi}_{10} / \mathrm{C}$ catalysts are lower than the EASA of $\mathrm{Pd}_{70} \mathrm{Ni}_{20} \mathrm{Bi}_{10} / \mathrm{C}$ (Fig. 4(j) and Table 3). The $\mathrm{Pd}_{70} \mathrm{Ni}_{25} \mathrm{Bi}_{5} / \mathrm{C}$ and $\mathrm{Pd}_{80} \mathrm{Ni}_{10} \mathrm{Bi}_{10} / \mathrm{C}$ catalysts also show lower stability than $\mathrm{Pd}_{70} \mathrm{Ni}_{20} \mathrm{Bi}_{10} / \mathrm{C}$ in the $\mathrm{CA}$ measurements (Figs. 5(e) and $5(\mathrm{f}$ ) and Table 3). However, the results are still better than for $\mathrm{Pd}_{60} \mathrm{Ni}_{40} / \mathrm{C}$ (Table 3) showing the positive effect of Bi on the stability toward alkaline EOR.

\subsection{4 $P d_{70} \mathrm{Ni}_{20} B i_{10} / C$ as promising EOR catalyst}

It can be concluded that higher amounts of $\mathrm{Ni}$ in Pd-based anode catalysts for the alkaline DEFC enhance the activity for the EOR. In case of $\mathrm{Bi}$, it is confirmed that lower amounts of $\mathrm{Bi}$ enhance the activity and kinetics at the anode for the EOR in an alkaline medium. This was observed as a low onset potential and high peak current density for catalysts with low Bi concentration. It was also found that a higher concentration of $\mathrm{Bi}(20$ at.\%) improves the byproduct tolerance and the stability of the catalyst.

The $\mathrm{Pd}_{70} \mathrm{Ni}_{20} \mathrm{Bi}_{10} / \mathrm{C}$ catalyst is the most active catalyst toward alkaline EOR among all tested catalysts (Figs. $4(\mathrm{~g})$ and $4(\mathrm{k})$ ) and exhibits the second best results in terms of byproduct tolerance (Table 3). The maximum current density of $106 \mathrm{~mA} \cdot \mathrm{cm}^{-2}$ (mass activity: $1,889 \mathrm{~mA} \cdot \mathrm{mg}^{-1}$-relating to Pd loading) from the novel ternary $\mathrm{Pd}_{70} \mathrm{Ni}_{20} \mathrm{Bi}_{10} / \mathrm{C}$ catalyst is, despite agglomerations, an outstanding value for the alkaline EOR compared to Ref. [55] as well as to Table S21 in the ESM. Considerably higher maximum current densities of the ternary $\mathrm{Pd}_{70} \mathrm{Ni}_{20} \mathrm{Bi}_{10} / \mathrm{C}$ catalyst could be achieved under the $\mathrm{CV}$ measurement conditions (e.g. with a scan rate of $50 \mathrm{mV} \cdot \mathrm{s}^{-1}$ instead of $10 \mathrm{mV} \cdot \mathrm{s}^{-1}$ ) applied in Ref. [55] and Table S21 in the ESM.

The electrochemical characterization results of all carbon supported Pd-based nanocatalysts are summarized in Table 3. Further details about the effects of the Pd, Ni and Bi species/ions on the catalytic properties and surface structures are discussed in the ESM.

\section{Conclusions}

Carbon supported Pd-based nanocatalysts ( $\mathrm{Pd} / \mathrm{C}, \mathrm{Pd}_{60} \mathrm{Ni}_{40} / \mathrm{C}$, $\mathrm{Pd}_{60} \mathrm{Bi}_{40} / \mathrm{C}$ and $\mathrm{Pd}_{x} \mathrm{Ni}_{y} \mathrm{Bi}_{z} / \mathrm{C}$ ) were successfully developed using the instant reduction synthesis method with $\mathrm{NaBH}_{4}$ as reducing agent, comprehensively characterized and the influence of the admetals $\mathrm{Ni}$ and Bi in the carbon supported binary and ternary Pd-based EOR catalysts was determined.

The alkaline EOR performance (catalytic activity, byproduct tolerance, and stability) of the novel carbon supported ternary $\mathrm{Pd}_{x} \mathrm{Ni}_{y} \mathrm{Bi}_{z}$ catalyst was optimized by varying the atomic ratios of $\mathrm{Pd}$, $\mathrm{Ni}$ and Bi for the application in alkaline direct ethanol fuel cells. The carbon supported Pd:Ni:Bi catalyst with the atomic ratio of 70:20:10 exhibits the highest catalytic activity compared to the other synthesized $\mathrm{Pd}_{x} \mathrm{Ni}_{y} \mathrm{Bi}_{z} / \mathrm{C}$ catalysts as well as to the benchmarks $\mathrm{Pd} / \mathrm{C}$, $\mathrm{Pd}_{60} \mathrm{Ni}_{40} / \mathrm{C}$ and $\mathrm{Pd}_{60} \mathrm{Bi}_{40} \mathrm{C}$. The maximum onset potential reduction of $116 \mathrm{mV}$ and the peak current density enhancement of $71 \mathrm{~mA} \cdot \mathrm{cm}^{-2}$ were achieved for the alkaline EOR on the $\mathrm{Pd}_{70} \mathrm{Ni}_{20} \mathrm{Bi}_{10} \mathrm{C}$ catalyst.

The low Bi content ( $\leq 10$ at.\%) in the synthesized ternary $\mathrm{Pd}_{x} \mathrm{Ni}_{y} \mathrm{Bi}_{z}$ catalysts promotes the alkaline EOR kinetics leading to high current densities and low onset potentials, whereas the use of high amounts of $\mathrm{Bi}$ (> 20 at.\%) blocks the active sites of the used catalysts resulting in a decrease of the EOR activities.

For further improvement of the EOR performance of the $\mathrm{Pd}_{70} \mathrm{Ni}_{20} \mathrm{Bi}_{10} / \mathrm{C}$ catalyst, the substitution of the support material and alternative deposition methods for spherical metal nanoparticles with defined particle size and low tendency to agglomeration are investigated.

\section{Acknowledgements}

Financial support from the Austrian Climate Energy Fund, Austrian Federal Ministry of Transport, Innovation and Technology (BMVIT), The Austrian Research Promotion Agency (FFG) through the program "Energy Mission Austria" and the IEA research cooperation are gratefully acknowledged. We thank Dr. Christian Palfinger for performing of the XPS analysis. 
Funding: Open access funding provided by Graz University of Technology

Electronic Supplementary Material: Supplementary material (further details of the ICP-OES, TEM-EDX, XRD, XPS and CV measurements) is available in the online version of this article at https://doi.org/10.1007/s12274-019-2277-z.

Open Access: This article is licensed under a Creative Commons Attribution 4.0 International License, which permits use, sharing, adaptation, distribution and reproduction in any medium or format, as long as you give appropriate credit to the original author(s) and the source, provide a link to the Creative Commons licence, and indicate if changes were made.

The images or other third party material in this article are included in the article's Creative Commons licence, unless indicated otherwise in a credit line to the material. If material is not included in the article's Creative Commons licence and your intended use is not permitted by statutory regulation or exceeds the permitted use, you will need to obtain permission directly from the copyright holder.

To view a copy of this licence, visit http://creativecommons.org/ licenses/by/4.0/.

\section{References}

[1] An, L.; Zhao, T. S.; Li, Y. S. Carbon-neutral sustainable energy technology: Direct ethanol fuel cells. Renew. Sustain. Energy Rev. 2015, 50, 1462-1468.

[2] Zhang, Z. Y.; Xin, L.; Sun, K.; Li, W. Z. Pd-Ni electrocatalysts for efficient ethanol oxidation reaction in alkaline electrolyte. Int. J. Hydrogen Energy 2011, 36, 12686-12697.

[3] Shen, S. Y.; Zhao, T. S.; Wu, Q. X. Product analysis of the ethanol oxidation reaction on palladium-based catalysts in an anion-exchange membrane fuel cell environment. Int. J. Hydrogen Energy 2012, 37, 575-582.

[4] Shen, S. Y.; Zhao, T. S.; Xu, J. B.; Li, Y. S. Synthesis of PdNi catalysts for the oxidation of ethanol in alkaline direct ethanol fuel cells. J. Power Sources 2010, 195, 1001-1006.

[5] Zhao, T. S.; Li, Y. S.; Shen, S. Y. Anion-exchange membrane direct ethanol fuel cells: Status and perspective. Front. Energy Power Eng. China 2010, 4, 443-458.

[6] An, L.; Zhao, T. S. Transport phenomena in alkaline direct ethanol fuel cells for sustainable energy production. J. Power Sources 2017, 341, 199-211.

[7] Neto, A. O.; Tusi, M. M.; de Oliveira Polanco, N. S.; da Silva, S. G.; Santos, M. C.; Spinacé, E. V. PdBi/C electrocatalysts for ethanol electro-oxidation in alkaline medium. Int. J. Hydrogen Energy 2011, 36, 10522-10526.

[8] Wu, Q. M.; Jiang, L. H.; Qi, L. T.; Yuan, L. Z.; Wang, E. D.; Sun, G. Q. Electrocatalytic activity and stability of $\mathrm{Ag}-\mathrm{MnO}_{x} / \mathrm{C}$ composites toward oxygen reduction reaction in alkaline solution. Electrochim. Acta 2014, $123,167-175$.

[9] Wang, Y.; Shi, F. F.; Yang, Y. Y.; Cai, W. B. Carbon supported Pd-Ni-P nanoalloy as an efficient catalyst for ethanol electro-oxidation in alkaline media. J. Power Sources 2013, 243, 369-373.

[10] Yu, E. H.; Wang, X.; Krewer, U.; Li, L.; Scott, K. Direct oxidation alkaline fuel cells: From materials to systems. Energy Environ. Sci. 2012, 5, $5668-5680$.

[11] Kamarudin, M. Z. F.; Kamarudin, S. K.; Masdar, M. S.; Daud, W. R. W. Review: Direct ethanol fuel cells. Int. J. Hydrogen Energy 2013, 38, 9438-9453.

[12] Su, P. C.; Chen, H. S.; Chen, T. Y.; Liu, C. W.; Lee C. H.; Lee, J. F.; Chan, T. S.; Wang, K. W. Enhancement of electrochemical properties of $\mathrm{Pd} / \mathrm{C}$ catalysts toward ethanol oxidation reaction in alkaline solution through $\mathrm{Ni}$ and Au alloying. Int. J. Hydrogen Energy 2013, 38, 4474-4482.

[13] Singh, R. N.; Anindita, A. S. Electrocatalytic activity of binary and ternary composite films of Pd, MWCNT, and Ni for ethanol electro-oxidation in alkaline solutions. Carbon 2009, 47, 271-278.

[14] Ma, L.; Chu, D.; Chen, R. R. Comparison of ethanol electro-oxidation on $\mathrm{Pt} / \mathrm{C}$ and $\mathrm{Pd} / \mathrm{C}$ catalysts in alkaline media. Int. J. Hydrogen Energy 2012, $37,11185-11194$.

[15] Geraldes, A. N.; da Silva, D. F.; Pino, E. S.; da Silva, J. C. M.; de Souza, R. F.
B.; Hammer, P.; Spinacé, E. V.; Neto, A. O.; Linardi, M.; dos Santos, M. C. Ethanol electro-oxidation in an alkaline medium using $\mathrm{Pd} / \mathrm{C}, \mathrm{Au} / \mathrm{C}$ and $\mathrm{PdAu} / \mathrm{C}$ electrocatalysts prepared by electron beam irradiation. Electrochim. Acta 2013, 111, 455-465.

[16] Shen, P. K.; Xu, C. W. Alcohol oxidation on nanocrystalline oxide Pd/C promoted electrocatalysts. Electrochem. Commun. 2006, 8, 184-188.

[17] Ma, L.; He, H.; Hsu, A.; Chen, R. R. PdRu/C catalysts for ethanol oxidation in anion-exchange membrane direct ethanol fuel cells. J. Power Sources 2013, 241, 696-702.

[18] Liang, Z. X.; Zhao, T. S.; Xu, J. B.; Zhu, L. D. Mechanism study of the ethanol oxidation reaction on palladium in alkaline media. Electrochim. Acta 2009, 54, 2203-2208.

[19] Zhu, F. C.; Wang, M.; He, Y. W.; Ma, G. S.; Zhang, Z. H.; Wang, X. G. A comparative study of elemental additives ( $\mathrm{Ni}, \mathrm{Co}$ and $\mathrm{Ag}$ ) on electrocatalytic activity improvement of PdSn-based catalysts for ethanol and formic acid electro-oxidation. Electrochim. Acta 2014, 148, 291-301.

[20] Moraes, L. P. R.; Matos, B. R.; Radtke, C.; Santiago, E. I.; Fonseca, F. C.; Amico, S. C.; Malfatti, C. F. Synthesis and performance of palladium-based electrocatalysts in alkaline direct ethanol fuel cell. Int. J. Hydrogen Energy 2016, 41, 6457-6468.

[21] Tusi, M. M.; Polanco, N. S. O.; da Silva, S. G.; Spinacé, E. V.; Neto, A. O. The high activity of $\mathrm{PtBi} / \mathrm{C}$ electrocatalysts for ethanol electro-oxidation in alkaline medium. Electrochem. Commun. 2011, 13, 143-146.

[22] Nikiforova, T. G.; Datskevich, O. A.; Maleev, V. V. Palladium catalysts on porous nickel substrates for alcohol fuel cells. Russ. J. Appl. Chem. 2012, 85, 1871-1878.

[23] Yang, H. J.; Wang, H.; Li, H.; Ji, S.; Davids, M. W.; Wang, R. F. Effect of stabilizers on the synthesis of palladium-nickel nanoparticles supported on carbon for ethanol oxidation in alkaline medium. J. Power Sources 2014, $260,12-18$.

[24] Modibedi, R. M.; Masombuka, T.; Mathe, M. K. Carbon supported Pd-Sn and $\mathrm{Pd}-\mathrm{Ru}-\mathrm{Sn}$ nanocatalysts for ethanol electro-oxidation in alkaline medium. Int. J. Hydrogen Energy 2011, 36, 4664-4672.

[25] Shen, S. Y.; Zhao, T. S.; Xu, J. B.; Li, Y. S. High performance of a carbon supported ternary PdIrNi catalyst for ethanol electro-oxidation in anionexchange membrane direct ethanol fuel cells. Energy Environ. Sci. 2011, 4, $1428-1433$

[26] Dutta, A.; Datta, J. Outstanding catalyst performance of PdAuNi nanoparticles for the anodic reaction in an alkaline direct ethanol (with anion-exchange membrane) fuel cell. J. Phys. Chem. C 2012, 116, 25677-25688.

[27] Jiang, R. Z.; Tran, D. T.; McClure, J. P.; Chu, D. A class of (Pd-Ni-P) electrocatalysts for the ethanol oxidation reaction in alkaline media. $A C S$ Catal. 2014, 4, 2577-2586.

[28] Yi, Q. F.; Chu, H.; Chen, Q. H.; Yang, Z.; Liu, X. P. High performance Pd, $\mathrm{PdNi}, \mathrm{PdSn}$ and PdSnNi nanocatalysts supported on carbon nanotubes for electrooxidation of C2-C4 alcohols. Electroanal 2015, 27, 388-397.

[29] Jongsomjit, S.; Prapainainar, P.; Sombatmankhong, K. Synthesis and characterisation of $\mathrm{Pd}-\mathrm{Ni}-\mathrm{Sn}$ electrocatalyst for use in direct ethanol fuel cells. Solid State Ioncs 2016, 288, 147-153.

[30] Jana, R.; Dhiman, S.; Peter, S. C. Facile solvothermal synthesis of highly active and robust $\mathrm{Pd}_{1.87} \mathrm{Cu}_{0.11} \mathrm{Sn}$ electrocatalyst towards direct ethanol fuel cell applications. Mater. Res. Express 2016, 3, 084001.

[31] Rostami, H.; Abdollahi, T.; Mehdipour, P.; Rostami, A. A.; Farmanzadeh, D. Effect of $\mathrm{Ni}$ addition on electrocatalytic activity of $\mathrm{PdCu}$ catalysts for ethanol electrooxidation: An experimental and theoretical study. Int. J. Hydrogen Energy 2017, 42, 24713-24725.

[32] Yang, H. L.; Yu, Z. N.; Li, S. W.; Zhang, Q. L.; Jin, J.; Ma, J. T. Ultrafine palladium-gold-phosphorus ternary alloyed nanoparticles anchored on ionic liquids-noncovalently functionalized carbon nanotubes with excellent electrocatalytic property for ethanol oxidation reaction in alkaline media. $J$. Catal. 2017, 353, 256-264.

[33] Zhang, Y. Y.; Yi, Q. F.; Deng, Z. L.; Zhou, X. L.; Nie, H. D. Excellent electroactivity of ternary $\mathrm{Pd}-\mathrm{Ag}-\mathrm{Sn}$ nanocatalysts for ethanol oxidation. Catal. Lett. 2018, 148, 1190-1201.

[34] Shu, Y. L.; Shi, X. Q.; Ji, Y. Y.; Wen, Y.; Guo, X. Y.; Ying, Y.; Wu, Y. P.; Yang, H. F. Hollow echinus-like PdCuCo alloy for superior efficient catalysis of ethanol. ACS Appl. Mater. Interfaces 2018, 10, 4743-4749.

[35] Huang, Y. Y.; Guo, Y. L.; Wang, Y. B.; Yao, J. N. Synthesis and performance of a novel $\mathrm{PdCuPb} / \mathrm{C}$ nanocatalyst for ethanol electrooxidation in alkaline medium. Int. J. Hydrogen Energy 2014, 39, 4274-4281. 
[36] Bambagioni, V.; Bianchini, C.; Filippi, J.; Oberhauser, W.; Marchionni, A.; Vizza, F.; Psaro, R.; Sordelli, L.; Foresti, M. L.; Innocenti, M. Ethanol oxidation on electrocatalysts obtained by spontaneous deposition of palladium onto nickel-zinc materials. ChemSusChem 2009, 2, 99-112.

[37] Grimmer, C.; Grandi, M.; Zacharias, R.; Cermenek, B.; Weber, H.; Morais, C.; Napporn, T. W.; Weinberger, S.; Schenk, A.; Hacker, V. The electrooxidation of borohydride: A mechanistic study on palladium (Pd/C) applying RRDE, ${ }^{11}$ B-NMR and FTIR. Appl. Catal. B Environ. 2016, 180, 614-621.

[38] Reetz, M. T.; Lopez, M. Method for in situ immobilization of water-soluble nanodispersed metal oxide colloids. U.S. Patent 7,244,688, July 17, 2007.

[39] Piasentin, R. M.; Spinacé, E. V.; Tusi, M. M.; Oliveira Neto, A. Preparation of $\mathrm{PdPtSn} / \mathrm{C}-\mathrm{Sb}_{2} \mathrm{O}_{5} . \mathrm{SnO}_{2}$ electrocatalysts by borohydride reduction for ethanol electro-oxidation in alkaline medium. Int. J. Electrochem. Sci. 2011, 6, 2255-2263.

[40] Grimmer, C.; Zacharias, R.; Grandi, M.; Cermenek, B.; Schenk, A.; Weinberger, S.; Mautner, F. A.; Bitschnau, B.; Hacker, V. Carbon supported ruthenium as anode catalyst for alkaline direct borohydride fuel cells. J. Phys. Chem. C 2015, 119, 23839-23844.

[41] Grimmer, C.; Zacharias, R.; Grandi, M.; Pichler, B.; Kaltenboeck, I.; Gebetsroither, F.; Wagner, J.; Cermenek, B.; Weinberger, S.; Schenk, A. et al. A membrane-free and practical mixed electrolyte direct borohydride fuel cell. J. Electrochem. Soc. 2016, 163, F278-F283.

[42] Grimmer, C.; Grandi, M.; Zacharias, R.; Weinberger, S.; Schenk, A.; Aksamija, E.; Mautner, F. A.; Bitschnau, B.; Hacker, V. Carbon supported nanocrystalline manganese oxide: Surpassing platinum as oxygen reduction catalyst in direct borohydride fuel cells. J. Electrochem. Soc. 2016, 163, F885-F890.

[43] Cerritos, R. C.; Guerra-Balcázar, M.; Ramírez, R. F.; Ledesma-García, J.; Arriaga, L. G. Morphological effect of Pd catalyst on ethanol electro-oxidation reaction. Materials 2012, 5, 1686-1697.

[44] Wang, L. Q.; Lavacchi, A.; Bevilacqua, M.; Bellini, M.; Fornasiero, P.; Filippi, J.; Innocenti, M.; Marchionni, A.; Miller, H. A.; Vizza, F. Energy efficiency of alkaline direct ethanol fuel cells employing nanostructured palladium electrocatalysts. ChemCatChem 2015, 7, 2214-2221.

[45] Amin, R. S.; Abdel Hameed, R. M.; El-Khatib, K. M.; Elsayed Youssef, M. Electrocatalytic activity of nanostructured $\mathrm{Ni}$ and Pd-Ni on Vulcan XC-72R carbon black for methanol oxidation in alkaline medium. Int. J. Hydrogen Energy 2014, 39, 2026-2041.
[46] Simões, M.; Baranton, S.; Coutanceau, C. Influence of bismuth on the structure and activity of $\mathrm{Pt}$ and $\mathrm{Pd}$ nanocatalysts for the direct electrooxidation of $\mathrm{NaBH}_{4}$. Electrochim. Acta 2010, 56, 580-591.

[47] Obradović, M. D.; Stančić, Z. M.; Lačnjevac, U. Č; Radmilović, V. V.; Gavrilović-Wohlmuther, A.; Radmilović, V. R.; Gojković, S. L. Electrochemical oxidation of ethanol on palladium-nickel nanocatalyst in alkaline media. Appl. Catal. B Environ. 2016, 189, 110-118.

[48] Shinozaki, K.; Zack, J. W.; Richards, R. M.; Pivovar, B. S.; Kocha, S. S. Oxygen reduction reaction measurements on platinum electrocatalysts utilizing rotating disk electrode technique. J. Electrochem. Soc. 2015, 162, F1144-F1158.

[49] Pollet, B. G.; Goh, J. T. E. The importance of ultrasonic parameters in the preparation of fuel cell catalyst inks. Electrochim. Acta 2014, 128, 292-303.

[50] Casella, I. G.; Contursi, M. Characterization of bismuth adatom-modified palladium electrodes: The electrocatalytic oxidation of aliphatic aldehydes in alkaline solutions. Electrochim. Acta 2006, 52, 649-657.

[51] Sekol, R. C.; Carmo, M.; Kumar, G.; Gittleson, F.; Doubek, G.; Sun, K.; Schroers, J.; Taylor, A. D. Pd-Ni-Cu-P metallic glass nanowires for methanol and ethanol oxidation in alkaline media. Int. J. Hydrogen Energy 2013, 38, 11248-11255.

[52] Paschos, O.; Simonov, A. N.; Bobrovskaya, A. N.; Hantel, M.; Rzepka, M.; Dotzauer, P.; Popov, A. N.; Simonov, P. A.; Parmon, V. N.; Stimming, U. Bismuth modified $\mathrm{Pd} / \mathrm{C}$ as catalysts for hydrogen related reactions. Electrochem. Commun. 2010, 12, 1490-1492.

[53] Hofstead-Duffy, A. M.; Chen, D. J.; Sun, S. G.; Tong, Y. J. Origin of the current peak of negative scan in the cyclic voltammetry of methanol electro-oxidation on Pt-based electrocatalysts: A revisit to the current ratio criterion. J. Mater. Chem. 2012, 22, 5205-5208.

[54] Zhao, Y. Z.; Li, X. M.; Schechter, J. M.; Yang, Y. A. Revisiting the oxidation peak in the cathodic scan of the cyclic voltammogram of alcohol oxidation on noble metal electrodes. RSC Adv. 2016, 6, 5384-5390.

[55] Brouzgou, A.; Podias, A.; Tsiakaras, P. PEMFCs and AEMFCs directly fed with ethanol: A current status comparative review. J. Appl. Electrochem. 2013, 43, 119-136.

[56] Mondal, A.; De, A.; Datta, J. Cost effective and energy efficient catalytic support of $\mathrm{Co}$ and $\mathrm{Ni}$ in $\mathrm{Pd}$ matrix toward ethanol oxidation reaction: Product analysis and mechanistic interpretation. Appl. Catal. A: Gen. 2018, $561,87-95$. 